\title{
Profiling of apoptosis- and autophagy-associated molecules in human lung cancer A549 cells in response to cisplatin treatment using stable isotope labeling with amino acids in cell culture
}

\author{
ZONGQIANG WANG ${ }^{1}$, GUIFENG LIU ${ }^{2}$ and JINLAN JIANG ${ }^{3}$ \\ Departments of ${ }^{1}$ Medical Services and ${ }^{2}$ Radiology; ${ }^{3}$ Science Research Center, Department of Orthopedics, \\ China-Japan Union Hospital of Jilin University, Changchun, Jilin 130033, P.R. China
}

Received January 23, 2018; Accepted October 1, 2018

DOI: $10.3892 /$ ijo.2019.4690

\begin{abstract}
Cis-diammine-dichloro-platinum II-based adjuvant chemotherapy provides an alternative therapy to improve the survival of patients with lung tumors, especially those with non-small cell lung cancer (NSCLC). However, drug resistance is a large clinical problem and its underlying mechanism remains unclear. In the present study, NSCLC A549 cells were treated with a low concentration of cisplatin in order to observe and determine the development of chemoresistance, via growth curves, colony forming assays and apoptosis assays. Then the induction of autophagy was examined in the cisplatin-treated A549 cells with a fluorescence reporter. Profiled proteins in the cisplatin-treated A549 cells were also assessed using the stable isotope labeling by amino acids in cell culture (SILAC) method, and then the differentially expressed molecules were verified. The results demonstrated that A549 cells became less sensitive to cisplatin [resistant A549 cells (A549R)] following 20 passages in the medium containing a low concentration of cisplatin, with less apoptotic cells post-cisplatin treatment. A549R cells grew more efficiently in the cisplatin medium, with more colony formation and more cells migrating across the baseline. In addition, NSCLC results demonstrated that more autophagy-related proteins (ATGs) were expressed in the A549R cells. Furthermore, the western blotting results confirmed this upregulation of ATGs in A549R cells. In addition, two repeated SILAC screening
\end{abstract}

Correspondence to: Dr Jinlan Jiang, Science Research Center, Department of Orthopedics, China-Japan Union Hospital of Jilin University, 126 Xiantai Street, Erdao, Changchun, Jilin 130033, P.R. China

E-mail: jiadkankg@163.com

Dr Guifeng Liu, Department of Radiology, China-Japan Union Hospital of Jilin University, 126 Xiantai Street, Erdao, Changchun, Jilin 130033, P.R. China

E-mail: jlfsliuguifeng@163.com

Key words: autophagy, chemotherapy, non-small cell lung cancer, stable isotope labeling by amino acids in cell culture experiments recognized 15 proteins [glucose-regulated protein, $78 \mathrm{kDa}$ (GRP78), heat shock protein 71, pre-mRNA processing factor 19 , polypyrimidine tract binding protein 1 , translationally controlled tumor protein, Cathepsin D, Cytochrome $c$, thioredoxin domain containing 5, MutS homolog (MSH) 6, Annexin A2 (ANXA2), BRCA2 and Cyclin dependent kinase inhibitor $1 \mathrm{~A}$ interacting protein, $\mathrm{MSH} 2$, protein phosphatase $2 \mathrm{~A} 55 \mathrm{kDa}$ regulatory subunit $\mathrm{B} \alpha$, Rho glyceraldehyde-3-phosphate-dissociation inhibitor 1 and ANXA4] that were upregulated by $>1.5$-fold in heavy $(\mathrm{H})$ - and light (L)-labeled A549R cells. In addition, 16 and 14 proteins were downregulated by $>1.5$-fold in the $\mathrm{H}$ - and L-labeled A549R cells, respectively. The majority of the downregulated proteins were associated with apoptosis. In conclusion, the present study isolated a cisplatin-resistant human lung cancer A549 cell clone, with reduced apoptosis and high levels of autophagy, in response to cisplatin treatment. In cisplatin-resistant A549R cells, SILAC proteomics recognized the high expression of GRP78 and other proteins that are associated with anti-apoptosis and/or autophagy promotion.

\section{Introduction}

Lung cancer leads to high levels of cancer morbidity and cancer-associated mortality worldwide (1). Lung cancers are clinically classified as non-small-cell lung cancer (NSCLC; accounts for $80-85 \%$ of cases) and small cell lung cancer (SCLC) (2). Surgical resection is the most potentially curative therapeutic modality for this disease. Cis-diammine-dichloro-platinum II-based adjuvant chemotherapy significantly improves the prognosis of patients with advanced NSCLC (3), particularly in those with Stage II-IIIA $(4,5)$. However, innate non-sensitiveness to or acquired resistance to cisplatin is a major challenge in the management of patients with lung cancer $(6,7)$. Therefore, the identification of mechanisms underlining cisplatin chemoresistance in NSCLC is urgently required.

Advances in technology, including DNA sequencing, reverse transcription-quantitative polymerase chain reaction (RT-qPCR) and microarray methods, enable the discovery of predictive markers and the identification of significant expression at the transcriptional level of 
chemoresistance-associated genes $(6,7)$. In particular, the profiling by microarray screening is highly effective in predicting chemotherapeutic sensitivity, with thousands of genes being simultaneously evaluated (8-10). However, the relatively low sensitivity and poor lower thresholds of microarray detection reduce its accuracy; thus, follow-up quantitative methods are required to confirm the results.

Stable isotope labeling by amino acids in cell culture (SILAC) is effective in distinguishing the protein profiling from one group to the other (11-13). Five passages would transform $\sim 97 \%$ of ${ }^{12} \mathrm{C}$-labeled amino acids in A549 cells into ${ }^{13} \mathrm{C}$-labeled amino acids $\left[1-(1 / 2)^{5}=97 \%\right]$ and thus, cells only contain 'heavy' proteins $(11,13)$. The incorporation of stable isotopes facilitates the quantitative recognition of the differences in expression profiles by tandem mass spectrometry between the ${ }^{12} \mathrm{C}$ - and ${ }^{13} \mathrm{C}$-labeled $\mathrm{A} 549$ cells. SILAC has also been useful in the identification of cancer biomarkers, and chemoresistance-associated biomarkers in hepatocellular carcinoma (14), breast cancer (15) and lung cancer $(16,17)$.

In the present study, a cisplatin-resistant A549 cell clone (A549R) was isolated from A549 cells post-serial passages under cisplatin pressure. The differences in proliferation, apoptosis and autophagy were investigated between A549R and A549 cells under cisplatin treatment. Then the SILAC method was utilized to profile A549R specific proteomics under cisplatin treatment. The results implied that autophagy may be an important mechanism underlining the cisplatin resistance of NSCLC A549 cells.

\section{Materials and methods}

Reagents, cell culture, cisplatin-resistant clone selection and treatment. Human NSCLC A549 cells were purchased from American Type Culture Collection (Manassas, VA, USA) and were cultured in Dulbecco's modified Eagle's medium(DMEM; Gibco; Thermo Fisher Scientific, Inc., Waltham, MA, USA) supplemented with $10 \%$ fetal bovine serum (FBS; Invitrogen; Thermo Fisher Scientific, Inc.) at $37^{\circ} \mathrm{C}$, under $5 \% \mathrm{CO}_{2}$. For the selection of cisplatin-resistant clone, A549 (A549R) cells were seeded in 12-well plates (Corning Incorporated, Corning, NY, USA), with $<200$ cells per well, and were then incubated at $37^{\circ} \mathrm{C}$ for $3-5$ days with $1 \mu \mathrm{M}$ cisplatin (Sigma-Aldrich; Merck KGaA, Darmstadt, Germany). The larger cell colonies were picked and propagated with DMEM + 10\% FBS. Another 9 passages of selection were performed via colony forming assays with $1 \mu \mathrm{M}$ cisplatin treatment, which were followed by a further 10 passages of selection with $2 \mu \mathrm{M}$ cisplatin treatment. For A549R selection, A549 cells were cultured with $1 \mu \mathrm{M}$ cisplatin for 5 passages (without selection/purification of larger colonies), and then larger colonies were isolated after each passage for a further 5 passages with $1 \mu \mathrm{M}$ cisplatin. A similar selection process was performed for the isolation of colonies following treatment with $2 \mu \mathrm{M}$ cisplatin. For the stability examinations, A549R cells were cultured for an additional 20 passages in DMEM without cisplatin, then the colony forming and growth assays were performed; A549R cells prior to serial passaging were used as the control cells.

For heavy (H)- or light (L)-Lysine labeling experiments, A549 or A549R cells were cultured serially for 5 passages in SILAC ${ }^{\text {TM }}$ DMEM (Thermo Fisher Scientific, Inc.) supplemented with $10 \%$ FBS without Lysine, which was then respectively supplemented with ${ }^{13} \mathrm{C}_{6} \mathrm{H}_{14} \mathrm{~N}_{2} \mathrm{O}_{2}$-Lysine-HCL (H-labeled) or ${ }^{12} \mathrm{C}_{6} \mathrm{H}_{14} \mathrm{~N}_{2} \mathrm{O}_{2}$-Lysine-HCL (L-labeled). A total of $10 \mu \mathrm{M}$ cisplatin was added to each group of cells, which were incubated for $24 \mathrm{~h}$ at $37^{\circ} \mathrm{C}$ with $5 \% \mathrm{CO}_{2}$ in a $\mathrm{T} 75$ cell flask. For SILAC proteomics analysis, $\sim 1 \times 10^{7} \mathrm{H}$ - or L-labeled A549R/A549 cells with $80-90 \%$ confluence were collected for further analysis.

L- or H-labeled A549/A549R cells were collected and washed four times with $10 \mathrm{ml}$ ice-cold phosphate-buffered saline $(P B S)$ and counted. A total of $1 \times 10^{7} \mathrm{~L}$ - or H-labeled cells were lysed with $0.5 \%$ 4-Nonylphenol Ethoxylate (Santa Cruz Biotechnology, Inc., Dallas, TX, USA) containing $1.1 \mu \mathrm{M}$ pepstatin A (Sigma-Aldrich; Merck KGaA) on ice for $30 \mathrm{~min}$. Nuclei and other organelles were removed following centrifugation at $5,000 \mathrm{x}$ for $10 \mathrm{~min}$ at $4^{\circ} \mathrm{C}$. The supernatant protein samples were transferred to fresh tubes and then the protein concentration was quantified with a Bicinchoninic Acid protein assay (Thermo Fisher Scientific, Inc.). For SILAC analysis, the $\mathrm{H}$ - and L-labeled protein samples were mixed in a ratio of $1: 1$; the remaining samples were stored at $-80^{\circ} \mathrm{C}$ prior to subsequent use.

Colony forming, cell proliferation and migration assays. For the colony forming assay, 200 A549 or A549R cells were seeded in 12 -well plates and incubated at $37^{\circ} \mathrm{C}$ with DMEM containing 0 or $10 \mu \mathrm{M}$ cisplatin for 3-5 days. The cell colonies were stained at room temperature with $0.005 \%$ crystal violet for $10 \mathrm{~min}$ and observed with a UVP imaging system (UVP; LLC, Phoenix, AZ, USA). The colony number and size were quantified, respectively. To generate the growth curves of A549 or A549R cells, $10^{3}$ cells were incubated with DMEM containing 0 or $10 \mu \mathrm{M}$ cisplatin for $0,24,48$ or $72 \mathrm{~h}$ at $37^{\circ} \mathrm{C}$, under $5 \% \mathrm{CO}_{2}$. Then the cell number in each group was counted with the Olympus BX60 light microscope (Olympus Corporation, Tokyo, Japan). For the cell migration assay, A549 or A549R cells were cultured in $25 \mathrm{~cm}$ cell dishes with DMEM + 10\% FBS to $\sim 85 \%$ confluence, and were then scratched with a cell scratcher (Costar; Corning Incorporated). Cells were cultured for a further $24 \mathrm{~h}$ at $37^{\circ} \mathrm{C}$ with DMEM $+10 \%$ FBS, containing $2 \mu \mathrm{M}$ cisplatin. The number of cells that crossed the baseline was then counted as the number of migrating cells using the Olympus BX60 light microscope (Olympus Corporation).

Fluorescence-activated cell sorting (FACS) can flow analysis of apoptotic cells. A total of $1 \times 10^{6}$ A549 or A549R cells were treated at $37^{\circ} \mathrm{C}$ with or without $10 \mu \mathrm{M}$ cisplatin for $24 \mathrm{~h}$; then cells in each group were collected for flow cytometry analysis with a Annexin V-fluorescein isothiocyanate (FITC)/propidium iodide (PI) Apoptosis Detection kit (Abcam, Cambridge, UK). A549 or A549R cells were trypsinized with $0.125 \%$ trypsin and then suspended in $1 \mathrm{ml}$ binding buffer, to which $10 \mu \mathrm{l}$ Annexin V-FITC and $10 \mu \mathrm{l}$ PI were added successively for incubation at room temperature in the dark for $15 \mathrm{~min}$. The number of apoptotic cells was then determined using a FACScan flow cytometer (Bio-Rad Laboratories, Inc., Hercules, CA, USA) and analyzed using FlowJo version 10 (FlowJo LLC, Ashland, OR, USA). 
Imaging of autophagic puncta with green fluorescence protein (GFP)-light chain (LC)-3 reporter. For the imaging of autophagic vesicles (puncta), A549 or A549R cells were transfected with a GFP-LC3 reporter plasmid (1 $\mu \mathrm{g}$ per well of a 12-well plate; Biovector Science Laboratory, Beijing, China) for $6 \mathrm{~h}$ using Lipofectamine $3000^{\text {TM }}$ (Invitrogen; Thermo Fisher Scientific, Inc.). Fresh DMEM containing $2 \%$ FBS was added to the cells, which were then treated with or without $10 \mu \mathrm{M}$ cisplatin at $37^{\circ} \mathrm{C}$ for $24 \mathrm{~h}$. Treatment with $3 \mu \mathrm{M}$ Rapamycin (Sigma-Aldrich; Merck $\mathrm{KGaA}$ ) was taken as the positive autophagy induction control, and blank A549 or A549R cells (cells transfected with the GFP-LC3 reporter plasmid only) with fresh DMEM containing 2\% FBS was used as the blank control. A total of $5 \mathrm{nM} 3$-methyladenine (3MA; an autophagy inhibitor; Sigma-Aldrich; Merck KGaA) was utilized to inhibit cisplatin-induced autophagy in A549 or A549R cells via treatment for $24 \mathrm{~h}$ at $37^{\circ} \mathrm{C}$. Autophagic puncta were imaged and counted by confocal laser microscopy, and analyzed using FluoView software version 5.0 (both from Olympus Corporation).

Protein digestion, identification and quantification. The mixed H-/L-labeled protein sample was added into sodium dodecyl sulfate-polyacrylamide gel electrophoresis (SDS-PAGE) loading buffer and incubated in pre-boiled water for $3 \mathrm{~min}$. Proteins were then separated by electrophoresis with $12 \%$ SDS-PAGE (as described below) and stained with Coomassie Brilliant Blue at $26^{\circ} \mathrm{C}$ for $3 \mathrm{~h}$. The whole gel lane was sliced into 40 pieces according to Sun et al (18). The excised sections were homogenized and de-stained twice with a 1:1 ratio of $50 \mathrm{mM}$ Tris acetonitrile and $50 \mathrm{mM}$ ammonium bicarbonate solution (both from Sigma-Aldrich; Merck KGaA). The extraction of tryptic peptides from the gel was sequentially performed with 5\% Trifluoroacetate (Beijing Chemical Co., Ltd., Beijing, China) in the microwave oven at $750 \mathrm{~W}$ for $8 \mathrm{~min}$, and with $2.5 \%$ Trifluoroacetate and with $50 \%$ Tris acetonitrile in the microwave oven at $750 \mathrm{~W}$ for $8 \mathrm{~min}$. The extracts were pooled and dried completely by centrifugal lyophilization.

A mobile phase of $90 \mathrm{~min}$ at a flow rate of $300 \mathrm{nl} / \mathrm{min}$ was performed to separate each peptide mixture sample from the sliced gel, which were then subjected analysis with a Linear Trap Quadruple-Fourier Transform (LTQ-FT) mass spectrometer (Thermo Fisher Scientific, Inc.), which was equipped with a nanospray source and Agilent 1100 high-performance liquid chromatography system (Agilent Technologies, Inc., Santa Clara, CA, USA). The peptide eluent was introduced directly to an LTQ-FT mass spectrometer via electrospray ionization. Positively identified proteins were considered when at least two reliable peptides were matched and a protein score $>64$ was observed. The false positive rate of identified peptides was calculated as the ratio of total peptide hits in the reverse database to the number of peptide hits in the forward database above the same threshold. Identified proteins were quantified by SILAC-specific software (MSQuant 1.4.1; msquant.sourceforge.net) and inspected manually. Peptide abundances were calculated as ratios of the areas of the mono-isotopic peaks of the H-labeled versus the L-labeled peptides, and the protein ratios were calculated from the average of all quantified peptides of it.

Western blotting. Nuclear and cytosol fractions of the protein samples were isolated from A549 or A549R cells using a
Nuclear/Cytosol Fractionation kit (BioVision, Inc., Milpitas, CA, USA) and then a protease inhibitor (Sigma-Aldrich; Merck KGaA) was added. The concentration of each protein sample was determined using a BCA Protein Assay Reagent kit (Pierce; Thermo Fisher Scientific, Inc.), according to the manufacturer's instructions. Proteins ( $8 \mu \mathrm{g} / \mathrm{lane})$ were separated by $12 \%$ SDS-PAGE and transferred to a nitrocellulose membrane (EMD Millipore, Billerica, MA, USA) in order to separate the proteins in each sample by molecular weight. Then the membrane was blocked with $2 \%$ bovine serum albumin (Sigma-Aldrich; Merck $\mathrm{KGaA}$ ) at $4^{\circ} \mathrm{C}$ overnight, and then incubated with the rabbit or mouse anti-human LC3 (cat. no. sc-28266; 1:500), autophagy-related protein (Atg) 7 (cat. no. sc-517310; 1:500) or $\beta$-actin primary antibodies (cat. no. sc-517582; 1:1,000; all from Santa Cruz Biotechnology, Inc.) for $2 \mathrm{~h}$ at room temperature $\left(26^{\circ} \mathrm{C}\right)$. Membranes were then incubated with horseradish peroxidase (HRP)-conjugated anti-rabbit secondary antibodies [bovine anti-rabbit immunoglobulin G (IgG)-HRP: cat. no. sc-2379, 1:1,000; or bovine anti-mouse IgG-HRP: cat. no. sc-2380, 1:1,000; Santa Cruz Biotechnology, Inc.] for $1 \mathrm{~h}$ at room temperature $\left(26^{\circ} \mathrm{C}\right)$. Membranes were washed 4 times with 1X PBS-Tween-20 (0.1\% final concentration) prior to each incubation. The antigen-antibody binding was visualized with Enhanced chemiluminescence (Thermo Fisher Scientific, Inc.) using the UVP BioSpectrum 500 imaging system (UVP, LLC, Phoenix, AZ, USA) and ImageJ version 1.43b (National Institutes of Health, Bethesda, MD, USA).

Gene ontology $(G O)$ analysis. GO analyses were performed using DAVID 6.7 (david.ncifcrf.gov/). Apoptosis- and autophagy-associated genes were selected for analysis when the P-value of the correlation was $<0.05$.

Statistical analysis. SPSS 16.0 software (SPSS, Inc., Chicago, IL, USA) was utilized for statistical analysis. Quantitative results were presented as the mean \pm standard error of 3 or 4 repeated experiments. Statistical differences were analyzed with Student's t-test or one-way analysis of variance with Tukey's post hoc test. $\mathrm{P}<0.05$ was considered to indicate a statistically significant difference.

\section{Results}

Acquisition of cisplatin resistance in human lung cancer A549 cells following serial passages with cisplatin treatment. Cisplatin-resistant human lung cancer A549 cells (A549R cells) were obtained following serial passages under $1 \mu \mathrm{M}$ cisplatin ( 5 blind passages, then purification for another 5 passages) and then $2 \mu \mathrm{M}$ cisplatin ( 5 blind passages, then purification for another 5 passages) treatment via colony forming assays. As indicated in Fig. 1A, a phenotype with a larger colony size of A549 cells was obtained $(2.75 \pm 0.48$ vs. $1.32 \pm 0.26 ; \mathrm{P}<0.001)$. The level of proliferation in A549R cells was significantly higher than that of $\mathrm{A} 549$ cells, under treatment with $10 \mu \mathrm{M}$ cisplatin for 24,48 or $72 \mathrm{~h}(\mathrm{P}<0.05, \mathrm{P}<0.01$ or $\mathrm{P}<0.001$; Fig. 1B). Colony formation results also confirmed the difference in the level of proliferation between A549R and A549 cells (Fig. 1C). The colony number (Fig. 1D) and colony size (Fig. 1E) were greater in A549R cells post-treatment with $10 \mu \mathrm{M}$ cisplatin $(\mathrm{P}<0.05$ or $\mathrm{P}<0.001)$. In addition, a migration assay was performed for 

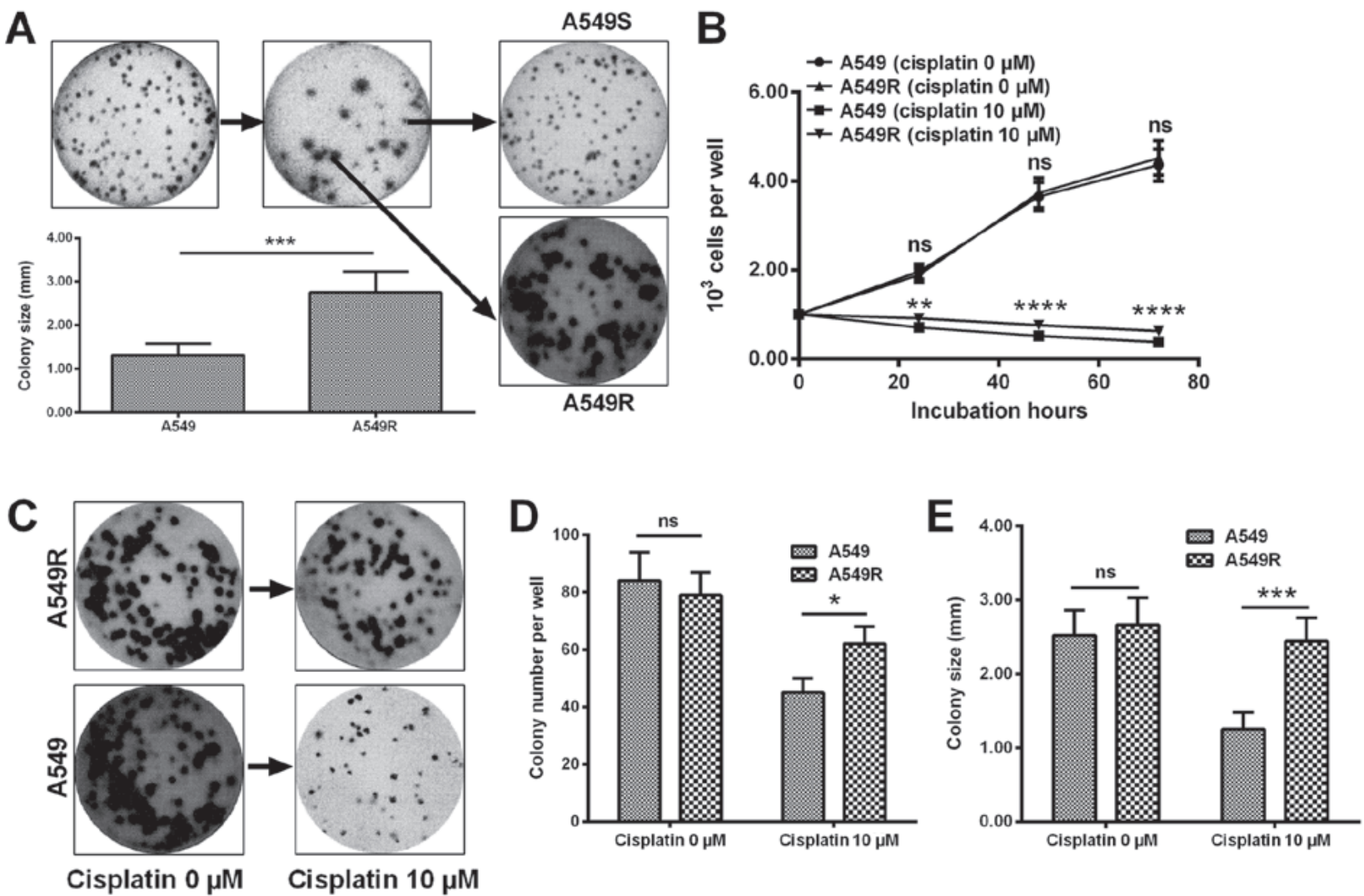

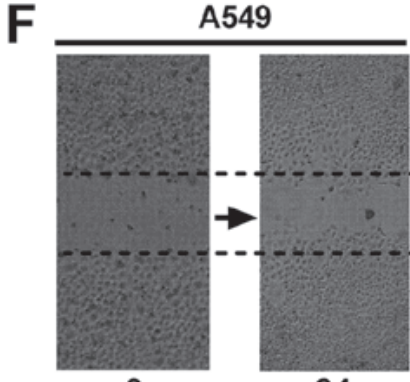

0

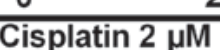

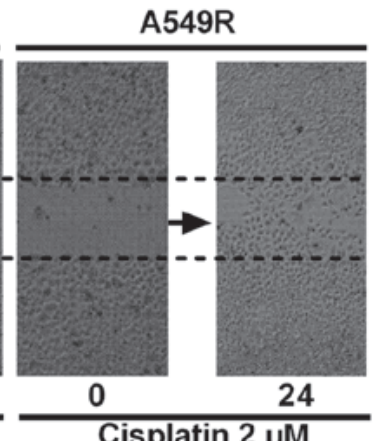

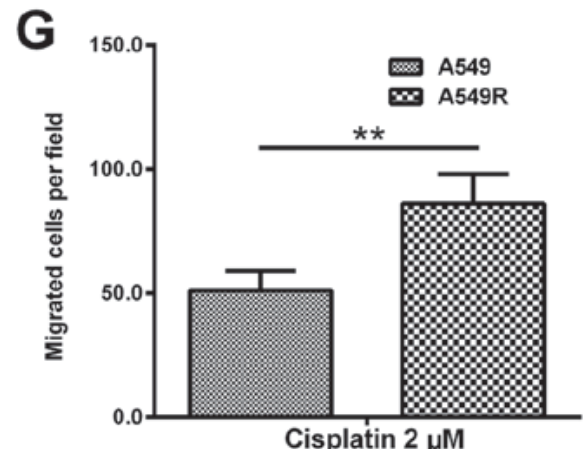

Figure 1. Isolation and determination of cisplatin-resistant human lung cancer A549 cells. (A) Colony forming assay for A549 cells, which were treated with $1 \mu \mathrm{M}$ cisplatin, then the colony with the greatest size was selected for another colony forming assay: 10 rounds of the selection under $1 \mu \mathrm{M}$ cisplatin treatment were followed by another 10 rounds of selection under $2 \mu \mathrm{M}$ cisplatin treatment. (B) Growth curve of A549 cells and the cisplatin-resistant A549R cells with or without $10 \mu \mathrm{M}$ cisplatin treatment. ${ }^{* * *} \mathrm{P}<0.01$ and ${ }^{* * * * *} \mathrm{P}<0.0001$ vs. the corresponding $0 \mu \mathrm{M}$ cisplatin group. (C-E) Colony forming assay (C) of A549 and A549R cells with or without $10 \mu \mathrm{M}$ cisplatin treatment, (D) the colony number and (E) the colony size were quantified for each group of cells. (F) Migration assay for A549 and A549R cells with $2 \mu \mathrm{M}$ cisplatin treatment (magnification, x20). (G) Migrated A549 and A549R cells were quantified. Results are presented as the mean \pm standard error of independent experiments. ${ }^{*} \mathrm{P}<0.05,{ }^{* *} \mathrm{P}<0.01$ and ${ }^{* * * *} \mathrm{P}<0.001$, as indicated. ns, not significant.

A549 and A549R cells in the presence of $2 \mu \mathrm{M}$ cisplatin. It was demonstrated in Fig. 1F and $\mathrm{G}$ that more cells crossed the baseline in the A549R cell group $(\mathrm{P}<0.01)$. Taken together, the results indicate that cisplatin resistance was acquired in A549 cells post 10 passages under cisplatin treatment.

In addition, A549R cells were cultured in DMEM without cisplatin for an additional 20 passages. It was indicated in Fig. 2A-C that there was no marked difference in growth efficiency between A549R and A549 cells.

Reduced apoptosis induction by cisplatin in the cisplatin-resistant A549R cells. To confirm the difference in the sensitivity to cisplatin between A549R and A549 cells, apoptosis induction of either A549R or A549 cells, post-treatment with
$10 \mu \mathrm{M}$ cisplatin for $24 \mathrm{~h}$ was examined by flow cytometry analysis following staining with the Annexin V-FITC/PI Apoptosis Detection kit. As presented in Fig. 3A-D, in contrast to the A549 (Fig. 3A) or A549R (Fig. 3B) cells without cisplatin treatment, treatment with $10 \mu \mathrm{M}$ cisplatin for $24 \mathrm{~h}$ induced significantly high levels of apoptosis in A549 and A549R cells $(\mathrm{P}<0.001$; Fig. 3C-E). Furthermore, there were less apoptotic cells in the A549R group (Fig. 3D and E) than in the A549 group following $10 \mu \mathrm{M}$ cisplatin treatment ( $\mathrm{P}<0.05$; Fig. $3 \mathrm{C}$ and $\mathrm{E})$. Therefore, these results confirmed resistance in A549R cells to cisplatin.

Autophagy induction by cisplatin in A549R cells. Autophagy has been supported by more studies as one of mechanisms 
A
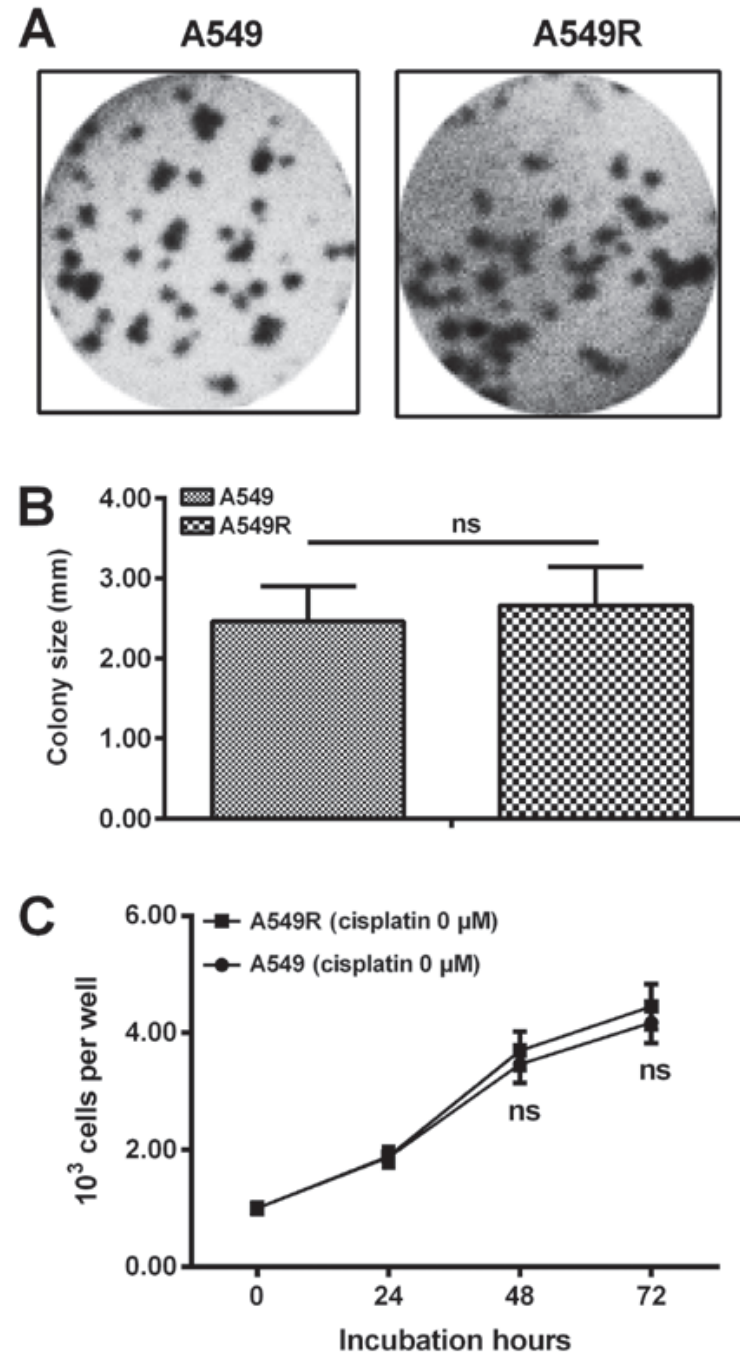

Figure 2. Growth determination of cisplatin-resistant or -sensitive A549 cells without cisplatin treatment. (A) Colony forming assay for the A549 or A549R cells, without cisplatin treatment. (B) The colony size was quantified for each group of cells. (C) Growth curve of A549 or A549R cells without cisplatin treatment. Results are presented as the mean \pm standard error of independent experiments. ns, not significant.

underlining the chemoresistance of lung cancer cells $(19,20)$. Firstly in the present study, autophagy-specific acidic vesicular organelles (AVOs) in A549R or A549 cells were observed under a fluorescence microscope with a GFP-LC3 reporter. When compared with the blank A549 or A549R cells, $10 \mu \mathrm{M}$ rapamycin induced significantly high levels of AVOs ( $\mathrm{P}<0.01$ or $\mathrm{P}<0.001$; Fig. 4A and $\mathrm{B})$. Notably, the $10 \mu \mathrm{M}$ cisplatin treatment also induced significant levels of AVOs in A549 and A549R cells ( $\mathrm{P}<0.01$ or $\mathrm{P}<0.001)$. In addition, this induction could be inhibited by the autophagy inhibitor $3 \mathrm{MA}$ in the two types of cells $(\mathrm{P}<0.01)$. Furthermore, more AVOs were induced by cisplatin in A549R cells, than in A549 cells $(\mathrm{P}<0.01$; Fig. 4B).

Western blotting was also performed to examine the expression of autophagy-associated genes in the cisplatin-treated A549 or A549R cells. Fig. 4C demonstrated that rapamycin and cisplatin induced a high level of LC3-I to LC3-II conversion and a high expression of Atg7 in A549 and A549R cells, both of which were inhibited by 3MA treatment. In addition, a greater LC3-II/LC3-I ratio and increased Atg7
A

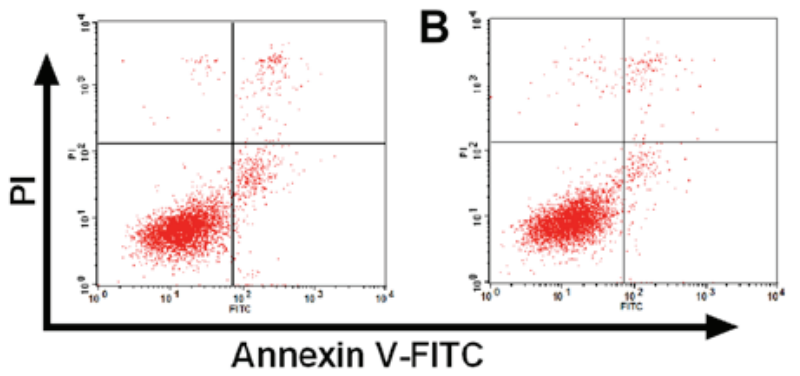

C

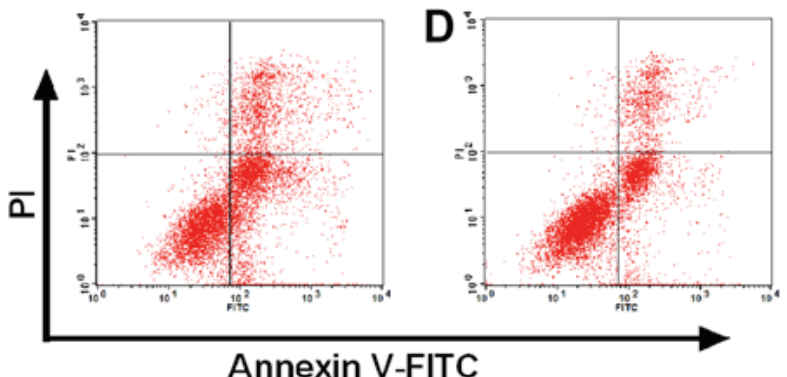

E

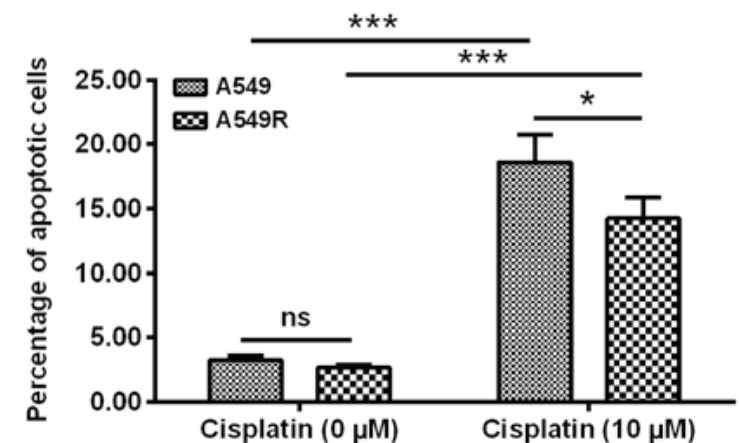

Figure 3. Flow cytometry analysis of apoptosis in A549 and A549R cells following $10 \mu \mathrm{M}$ cisplatin treatment. A549 cells were incubated with or without $10 \mu \mathrm{M}$ cisplatin for $24 \mathrm{~h}$, then the cells in each group were collected for flow cytometry analysis with Annexin V-FITC/PI. (A) A549 or (B) A549R cells with $0 \mu \mathrm{M}$ cisplatin for $24 \mathrm{~h}$; (C) A549 or (D) A549R cells with $10 \mu \mathrm{M}$ cisplatin for $24 \mathrm{~h}$. (E) Quantification of the number of apoptotic cells in each group. Results are presented as the mean \pm standard error of three independent experiments. ${ }^{*} \mathrm{P}<0.05$ and ${ }^{* * * *} \mathrm{P}<0.001$, as indicated. FITC, fluorescein isothiocyanate; PI, propidium iodide; ns, not significant.

expression were observed in the cisplatin-treated A549R cells when compared with the cisplatin-treated A549 cells.

General proteomics information by SILAC in the cisplatin-treated A549R cells. To recognize the discriminating protein profile underlining cisplatin resistance in A549R cells, a SILAC method was adopted to quantify the cellular response to cisplatin treatment in either A549 or A549R cells. The general technological process of SILAC is presented in Fig. 5A. The ${ }^{12} \mathrm{C}_{6} \mathrm{H}_{14} \mathrm{~N}_{2} \mathrm{O}_{2}$-Lysine-HCL (L-labeled) A549R cells (Fig. 5B) or the ${ }^{13} \mathrm{C}_{6} \mathrm{H}_{14} \mathrm{~N}_{2} \mathrm{O}_{2}$-Lysine-HCL (H-labeled) A549R cells (Fig. 5C) were respectively utilized to quantify the responsive protein profile to cisplatin, with $\mathrm{H}$-labeled or L-labeled A549 cells as control. To examine the quality of each procedure, cellular proteins were separated by $12 \%$ SDS-PAGE. As shown in Fig. 6A, protein bands were equally distributed in the H- or L-labeled A549R or A549 cells. The general difference in proteomics between A549R and A549 cells were summarized in Fig. 6B: Total of $1,161 \pm 152$ 

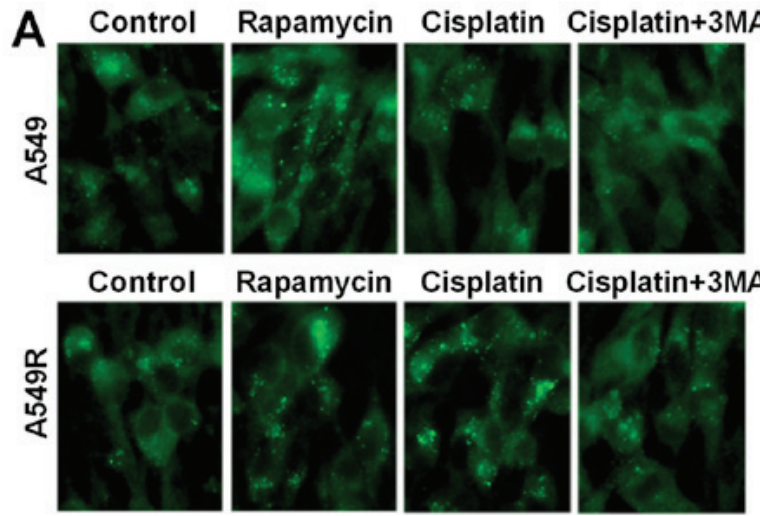

$B$

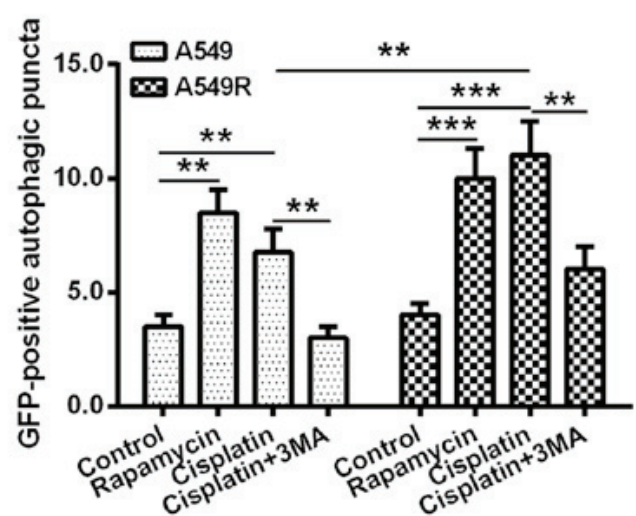

C

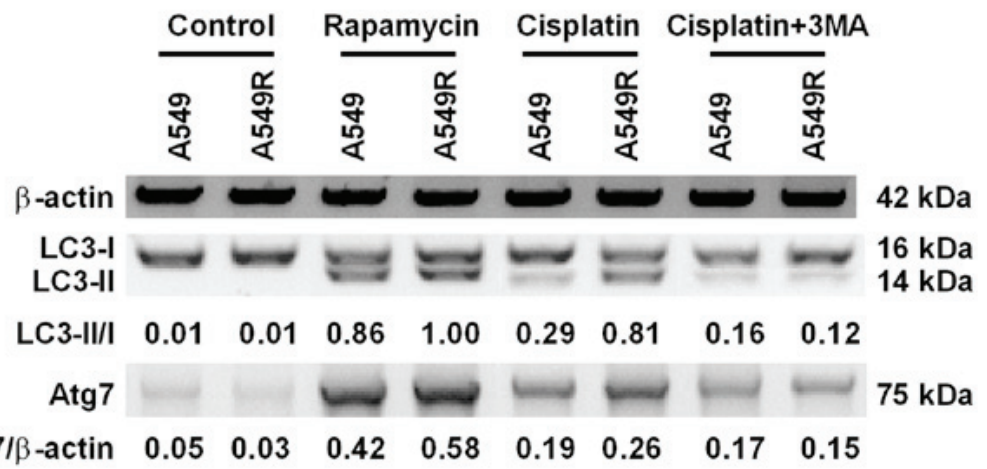

Figure 4. GFP-LC3 reporter assay for autophagy induction in the A549 or A549R cells following cisplatin treatment. (A) Autophagic puncta were observed in A549 or A549R cells following treatment with $10 \mu \mathrm{M}$ cisplatin, or with $10 \mu \mathrm{M}$ cisplatin and 5 nM 3MA (an autophagy inhibitor); blank and rapamycin treatment $(3 \mu \mathrm{M})$ were employed as the negative and positive controls, respectively (magnification, $\mathrm{x} 40$ ). (B) Number of autophagic puncta (GFP-positive) in each group of cells. (C) Western blot analysis of ATGs (conversion of LC3-I to LC3-II, and the level of ATG7) in each group of cells. Results were averaged for three independent replicate experiments. ${ }^{* *} \mathrm{P}<0.01$ and ${ }^{* * *} \mathrm{P}<0.001$, as indicated. GFP, green fluorescence protein; ATGs, autophagy-related genes; LC3, light chain 3; 3MA, 3-methyladenine.

A Cells in light, Cells in 12C6-Lys medium 13C6-Lys medium

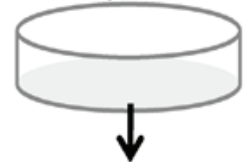

Whole proteome Whole proteome with 12C6-Lys with 13C6-Lys

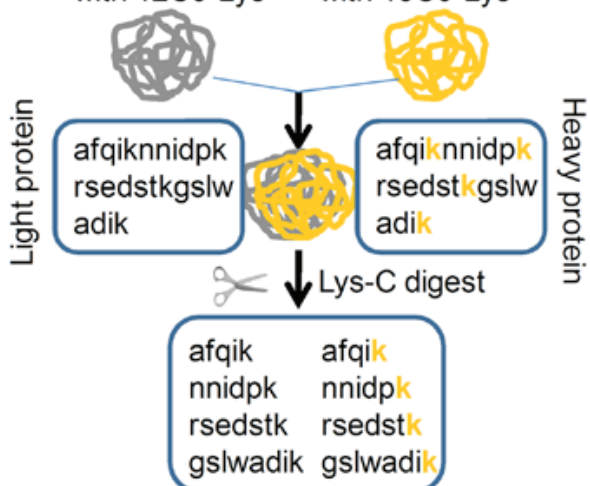

Analysis by MS
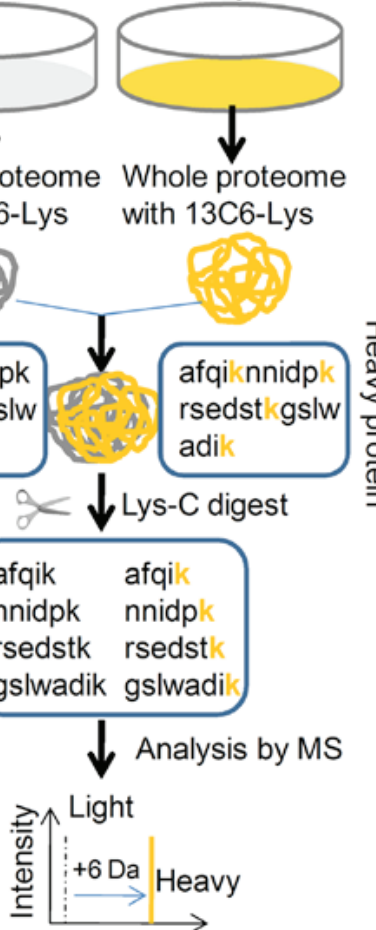

B

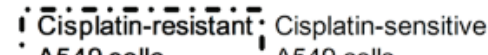
i. A549 cells. . . . A549 cells

C

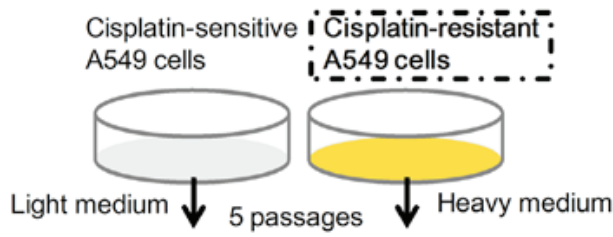

Whole proteome Whole proteome with 12C6-Lys with 13C6-Lys

Figure 5. Diagrammatic sketch of SILAC-based quantitative proteomics in A549 and A549R cells following cisplatin treatment. (A) SILAC-based quantitative proteomic. (B and C) SILAC-based quantitative proteomics in the (B) heavy medium-cultured A549 and (C) the heavy medium-cultured A549R cells following treatment with $10 \mu \mathrm{M}$ cisplatin for $24 \mathrm{~h}$. SILAC, stable isotope labeling with amino acids in cell culture; MS, mass spectrometry. 


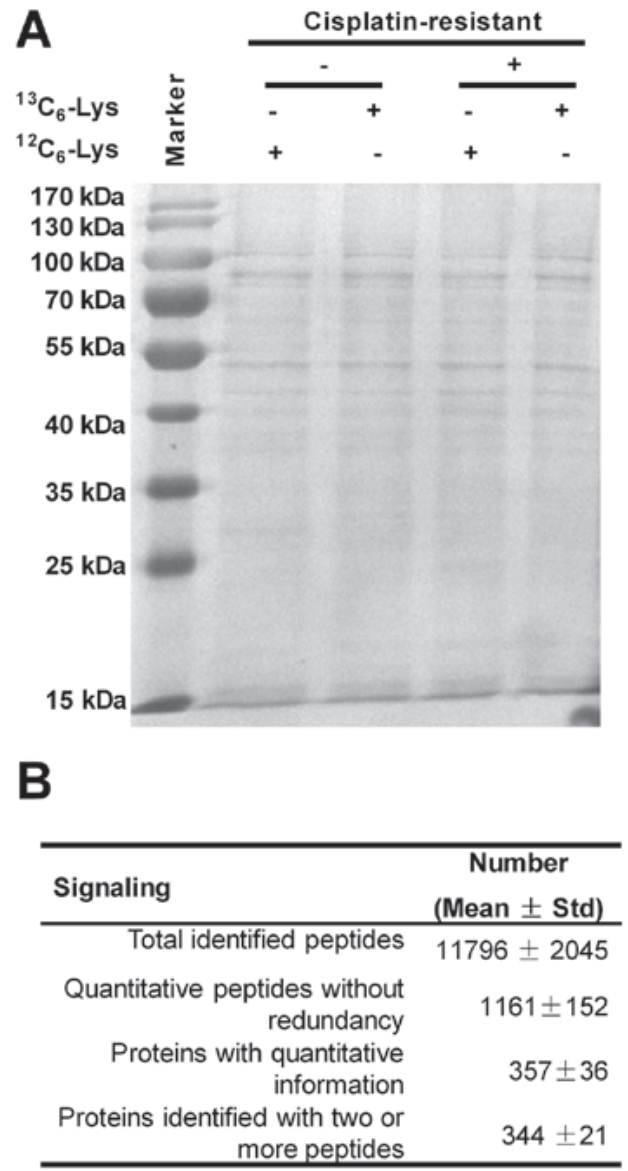

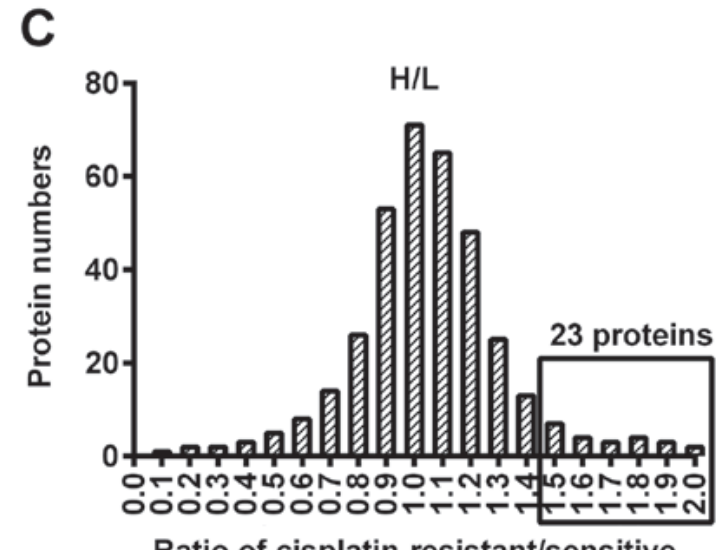

Ratio of cisplatin-resistant/sensitive

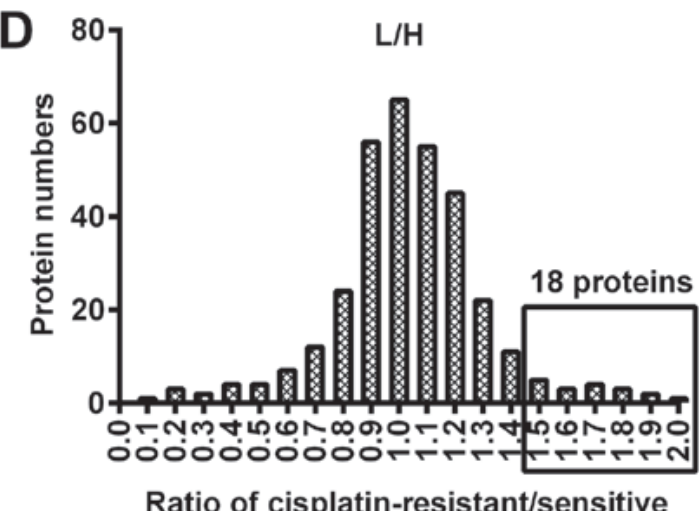

Figure 6. General information and gradient distribution of the cellular proteins in the heavy medium-cultured A549 or A549R cells following cisplatin treatment. (A) SDS-PAGE analysis of the heavy medium-cultured A549 and the heavy medium-cultured A549R cells following treatment with $10 \mu \mathrm{M}$ cisplatin for $24 \mathrm{~h}$. (B) General information regarding the proteomic results in the H/L-labeled A549/A549R cells following treatment with $10 \mu \mathrm{M}$ cisplatin for $24 \mathrm{~h}$. (C) Gradient distribution of the H-labeled A549R cells to L-labeled A549 cells following treatment with $10 \mu \mathrm{M}$ cisplatin. (D) Gradient distribution of the L-labeled A549R cells to H-labeled A549 cells following treatment with $10 \mu \mathrm{M}$ cisplatin. H-, heavy; L-, light; Std, standard deviation.

quantitative peptides, and $357 \pm 36$ proteins were induced by cisplatin $(10 \mu \mathrm{M})$ between A549R and A549 cells.

Upregulation of anti-apoptosis and autophagy-associated proteins in cisplatin-treated A549R cells via SILAC screening. Among the upregulated proteins in the H-labeled A549R cells, there were 23 proteins with expression that was $>1.5$-fold greater than in the L-labeled A549 cells (Fig. 6C). In particular, 15 proteins, including glucose-regulated protein, $78 \mathrm{kDa}$ (GRP78), heat shock protein 71 (HSP71), heterogeneous nuclear ribonucleoprotein A1 (ROA1) and pre-mRNA processing factor 19 (PRP19), had increased expression by >2-fold in the H-labeled A549R cells when compared with the L-labeled A549 cells (Table I). In another repeated experiment with L-labeled A549R cells and H-labeled A549 cells, there were 18 proteins recognized also with expression that was $>1.5$ fold greater (Fig. 6D; Table II). GO analysis indicated that the majority of the upregulated proteins were involved in anti-apoptosis, DNA repair and autophagy (Tables I and II). In addition, the two repeated experiments demonstrated that 15 proteins [GRP78, HSP71, PRP19, polypyrimidine tract binding protein 1 (PTBP1), translationally controlled tumor protein (TCTP), Cathepsin D (CATD), Cytochrome $c$ (CYC), thioredoxin domain containing 5 (TXND5), MutS homolog 6 (MSH6), Annexin A2 (ANXA2), RCA2 and
Cyclin dependent kinase inhibitor 1A interacting protein (BCCIP), MSH2, protein phosphatase 2A $55 \mathrm{kDa}$ regulatory subunit $\mathrm{B} \alpha$ (PP2AB), Rho glyceraldehyde-3-phosphate-dissociation inhibitor 1 (GDIR1) and ANXA4)] were repeatedly upregulated by $>1.5$-fold greater in $\mathrm{H}$ - and L-labeled A549R cells (Tables I and II).

Downregulation of apoptosis-associated proteins in cisplatin-treated A549R cells. In addition, there were 26 and 22 proteins that were downregulated $>1.5$-fold in the $\mathrm{H}$ - and L-labeled A549R cells, respectively, when compared with the L- and H-labeled A549 cells (Tables I and II). It was indicated in Table I that there were 16 proteins that were downregulated by $>1.5$-fold in H-labeled A549R cells when compared with L-labeled A549 cells. In another experiment, 14 proteins were revealed to be downregulated in L-labeled A549R cells when compared with the H-labeled A549 cells (Table II). Notably, the majority of the downregulated proteins were associated with apoptosis. In particular, 5 proteins [tumor necrosis factor receptor superfamily member 10B (TR10B), ubiquitin specific peptidase 17 (U17LO), SHB, PKN2, MTCH1) were downregulated in $\mathrm{H}$ - and L-labeled A549R cells; all of these proteins were involved in apoptotic processes or signaling. Therefore, apoptosis-associated proteins were downregulated in cisplatin-treated A549R cells. 
Table I. Proteins with >1.5-fold change (H/L) in expression levels in A549R cells when compared with A549 cells.

\begin{tabular}{|c|c|c|c|c|}
\hline $\begin{array}{l}\text { Accession } \\
\text { no. }\end{array}$ & Uniprot ID & Protein name & $\begin{array}{l}\text { Fold } \\
(\mathrm{H} / \mathrm{L})\end{array}$ & GO term name in biological pathway \\
\hline P11021* & GRP78 & $\begin{array}{l}78 \mathrm{kDa} \text { glucose-regulated } \\
\text { protein (bip) }\end{array}$ & 3.57 & $\begin{array}{l}\text { Anti-apoptosis, calcium ion binding, } \\
\text { enzyme binding, misfolded protein binding }\end{array}$ \\
\hline Q9UMS4* & PRP19 & Pre-mRNA-processing factor 19 & 3.28 & $\begin{array}{l}\text { DNA repair, ubiquitin-ubiquitin } \\
\text { ligase activity }\end{array}$ \\
\hline P13693* & TCTP & $\begin{array}{l}\text { Translationally-controlled } \\
\text { tumor protein (TCTP) }\end{array}$ & 3.12 & Anti-apoptosis in response to DNA damage \\
\hline P08107* & HSP71 & Heat shock $70 \mathrm{kDa}$ protein $1 \mathrm{~A} / 1 \mathrm{~B}$ & 2.75 & $\begin{array}{l}\text { Anti-apoptosis, cellular response to oxidative stress, } \\
\text { negative regulation of cell death }\end{array}$ \\
\hline P09651 & ROA1 & hnRNP core protein A1 (hnRNP A1) & 2.7 & $\begin{array}{l}\text { mRNA processing, negative regulation of } \\
\text { telomere maintenance via telomerase }\end{array}$ \\
\hline P26599* & PTBP1 & $\begin{array}{l}\text { Polypyrimidine tract-binding } \\
\text { protein } 1 \text { (hnRNP I) }\end{array}$ & 2.63 & $\begin{array}{l}\text { mRNA processing, mRNA splicing, } \\
\text { via spliceosome }\end{array}$ \\
\hline P08758 & ANXA5 & Annexin A5 (Annexin V) & 2.58 & $\begin{array}{l}\text { Anti-apoptosis, calcium-dependent } \\
\text { phospholipid binding }\end{array}$ \\
\hline P07339* & CATD & Cathepsin D & 2.56 & $\begin{array}{l}\text { Autophagic vacuole assembly, protein catabolic } \\
\text { process, proteolysis }\end{array}$ \\
\hline Q04760 & LGUL & $\begin{array}{l}\text { Lactoylglutathione lyase } \\
\text { (Aldoketomutase) }\end{array}$ & 2.43 & $\begin{array}{l}\text { Anti-apoptosis, regulation of transcription } \\
\text { by RNA polymerase II }\end{array}$ \\
\hline Q01081 & U2AF1 & $\begin{array}{l}\text { Splicing factor U2AF } 35 \mathrm{kDa} \\
\text { subunit }\end{array}$ & 2.37 & $\begin{array}{l}\text { mRNA processing, mRNA splicing, } \\
\text { via spliceosome, RNA export from nucleus }\end{array}$ \\
\hline P99999* & CYC & Cytochrome $\mathrm{C}$ & 2.31 & $\begin{array}{l}\text { Cellular respiration, cellular response to oxidative } \\
\text { stress, intrinsic apoptotic signaling pathway }\end{array}$ \\
\hline Q8NBS9* & TXND5 & $\begin{array}{l}\text { Thioredoxin domain-containing } \\
\text { protein } 5\end{array}$ & 2.25 & $\begin{array}{l}\text { Anti-apoptosis, protein folding, response to } \\
\text { endoplasmic reticulum stress }\end{array}$ \\
\hline P14625 & ENPL & $\begin{array}{l}\text { Heat shock protein } 90 \mathrm{kDa} \beta \\
\text { member } 1 \text { (GRP-94) }\end{array}$ & 2.12 & $\begin{array}{l}\text { Anti-apoptosis, RNA binding, unfolded } \\
\text { protein binding }\end{array}$ \\
\hline P52701* & MSH6 & $\begin{array}{l}\text { DNA mismatch repair protein } \\
\text { Msh6 (hmsh6) }\end{array}$ & 2.1 & $\begin{array}{l}\text { DNA damage response, methylated histone binding, } \\
\text { mismatched DNA binding }\end{array}$ \\
\hline $\mathrm{P} 07355^{*}$ & ANXA2 & Annexin A2 (Annexin II) & 2.01 & $\begin{array}{l}\text { Skeletal system development, phosphatidylinositol- } \\
\text { 4,5-bisphosphate binding, phospholipase A2 } \\
\text { inhibitor activity }\end{array}$ \\
\hline Q9P287* & BCCIP & $\begin{array}{l}\text { BRCA2 and CDKN1A- } \\
\text { interacting protein }\end{array}$ & 1.94 & $\begin{array}{l}\text { DNA repair, regulation of cyclin-dependent protein } \\
\text { serine/threonine kinase activity }\end{array}$ \\
\hline P43246* & MSH2 & $\begin{array}{l}\text { DNA mismatch repair protein } \\
\text { Msh2 (hmsh2) }\end{array}$ & 1.83 & $\begin{array}{l}\text { Mismatch repair, intrinsic apoptotic signaling } \\
\text { pathway in response to DNA damage by p53 } \\
\text { class mediator }\end{array}$ \\
\hline Q16531 & DDB1 & $\begin{array}{l}\text { DNA damage-binding protein } 1 \\
\text { (DDB p127 subunit) }\end{array}$ & 1.74 & $\begin{array}{l}\text { Nucleotide-excision repair, DNA damage response, } \\
\text { detection of DNA damage }\end{array}$ \\
\hline P13073 & COX41 & $\begin{array}{l}\text { Cytochrome C oxidase subunit } 4 \\
\text { isoform } 1(\mathrm{COX} \text { IV-1) }\end{array}$ & 1.71 & $\begin{array}{l}\text { Response to nutrient, mitochondrial electron } \\
\text { transport, Cytochrome } \mathrm{C} \text { to oxygen }\end{array}$ \\
\hline P62714* & $\mathrm{PP} 2 \mathrm{AB}$ & $\begin{array}{l}\text { Serine/threonine-protein } \\
\text { phosphatase } 2 \mathrm{~A} \text { catalytic subunit } \beta \\
\text { isoform }(\mathrm{PP} 2 \mathrm{~A}-\beta)\end{array}$ & 1.69 & $\begin{array}{l}\text { Protein amino acid dephosphorylation, apoptotic } \\
\text { mitochondrial changes, negative } \\
\text { regulation of Ras protein signal, } \\
\text { response to endoplasmic reticulum stress }\end{array}$ \\
\hline P52565* & GDIR1 & $\begin{array}{l}\text { Rho GDP-dissociation inhibitor } 1 \\
\text { (Rho GDI 1) }\end{array}$ & 1.67 & $\begin{array}{l}\text { Anti-apoptosis, regulation of Rho protein signal } \\
\text { transduction and of small GTPase mediated signal } \\
\text { transduction }\end{array}$ \\
\hline P62805 & $\mathrm{H} 4$ & Histone H4 & 1.56 & Negative regulation of megakaryocyte differentiation \\
\hline
\end{tabular}


Table I. Continued.

\begin{tabular}{|c|c|c|c|c|}
\hline $\begin{array}{l}\text { Accession } \\
\text { no. }\end{array}$ & Uniprot ID & Protein name & $\begin{array}{l}\text { Fold } \\
(\mathrm{H} / \mathrm{L})\end{array}$ & GO term name in biological pathway \\
\hline P09525* & ANXA4 & Annexin A4 (Annexin IV) & 1.51 & $\begin{array}{l}\text { Anti-apoptosis, negative regulation of } \mathrm{NF}-\kappa \mathrm{B} \\
\text { transcription factor activity }\end{array}$ \\
\hline Q15833 & STXB2 & Syntaxin-binding protein 2 & 0.66 & $\begin{array}{l}\text { Cellular response to interferon-gamma, } \\
\text { protein transport }\end{array}$ \\
\hline Q9NZJ7* & MTCH1 & Mitochondrial carrier homolog 1 & 0.66 & $\begin{array}{l}\text { Activation of cysteine-type endopeptidase } \\
\text { activity, apoptotic process }\end{array}$ \\
\hline O60218 & AK1BA & $\begin{array}{l}\text { Aldo-keto reductase } \\
\text { family } 1 \text { member B10 }\end{array}$ & 0.64 & $\begin{array}{l}\text { Aldo-keto reductase (NADP) activity, } \\
\text { geranylgeranyl reductase activity }\end{array}$ \\
\hline Q0WX57* & U17LO & $\begin{array}{l}\text { Ubiquitin-specific-processing } \\
\text { protease } 17\end{array}$ & 0.63 & $\begin{array}{l}\text { Apoptotic process, protein deubiquitination involved } \\
\text { in ubiquitin-dependent protein catabolic process }\end{array}$ \\
\hline P11498 & PYC & Pyruvate carboxylase, mitochondrial & 0.63 & $\begin{array}{l}\text { Biotin binding, identical protein binding, } \\
\text { biotin metabolic process }\end{array}$ \\
\hline P10909 & CLUS & Clusterin & 0.61 & $\begin{array}{l}\text { Chaperone binding, positive regulation of } \\
\text { apoptotic process }\end{array}$ \\
\hline Q16513* & PKN2 & Serine/threonine-protein kinase N2 & 0.59 & $\begin{array}{l}\text { Apoptotic process, cell adhesion, cell cycle } \\
\text { and cell division }\end{array}$ \\
\hline Q9HBU6 & EKI1 & Ethanolamine kinase 1 & 0.56 & $\begin{array}{l}\text { ATP binding, ethanolamine kinase activity, } \\
\text { phosphatidylethanolamine biosynthetic process }\end{array}$ \\
\hline Q9GZU2 & PEG3 & Paternally-expressed gene 3 protein & 0.53 & Apoptotic process, nucleic acid binding \\
\hline O95140 & MFN2 & Mitofusin-2 & 0.53 & GTP binding, apoptotic process, macroautophagy \\
\hline O14763* & TR10B & TRAIL receptor 2 & 0.52 & $\begin{array}{l}\text { Receptor for the cytotoxic ligand TNFSF10/TRAIL, } \\
\text { the adapter molecule FADD recruits caspase- } 8 \\
\text { to the activated receptor }\end{array}$ \\
\hline Q96S44 & PRPK & $\begin{array}{l}\text { EKC/KEOPS complex } \\
\text { subunit TP53RK }\end{array}$ & 0.47 & $\begin{array}{l}\text { ATP binding,p53 binding, protein } \\
\text { serine/threonine kinase activity }\end{array}$ \\
\hline I0J062 & PANO1 & Proapoptotic nucleolar protein 1 & 0.47 & $\begin{array}{l}\text { Positive regulation of apoptotic process, } \\
\text { regulation of protein stability }\end{array}$ \\
\hline Q15464* & SHB & $\begin{array}{l}\mathrm{SH} 2 \text { domain-containing } \\
\text { adapter protein } \mathrm{B}\end{array}$ & 0.46 & $\begin{array}{l}\text { Apoptotic process, cell differentiation, } \\
\mathrm{SH} 3 / \mathrm{SH} 2 \text { adaptor activity }\end{array}$ \\
\hline Q96FX8 & PERP & $\begin{array}{l}\text { P53 apoptosis effector related } \\
\text { to PMP-22 }\end{array}$ & 0.45 & $\begin{array}{l}\text { Notch signaling pathway, positive regulation of } \\
\text { proteolysis, regulation of apoptotic process }\end{array}$ \\
\hline P26447 & S10A4 & Protein S100-A4 & 0.38 & $\begin{array}{l}\text { Epithelial to mesenchymal transition, positive } \\
\text { regulation of } \mathrm{I}-\kappa \mathrm{B} \text { kinase/NF- } \mathrm{B} \text { signaling }\end{array}$ \\
\hline
\end{tabular}

Accession numbers marked with an asterisks $\left(^{*}\right)$ are those that are affected by either up- or downregulation. GO, Gene Ontology; $\mathrm{H}$, heavy-labeled; L, light-labeled.

\section{Discussion}

Cisplatin-based combinations of cytotoxic chemotherapy are the primary form of lung cancer chemotherapy as it significantly improves lung cancer patient outcomes $(3,4,21,22)$. Approximately $30 \%$ of patients with stage IV NSCLC are responsive to cisplatin-based, two-drug combination treatment, and $>95 \%$ patients live $>3$ years $(22,23)$. Even for patients with SCLC, their initial response rates to cisplatin combination are higher, at 50-80\%. However, almost all lung cancers are either initially or ultimately resistant to the current chemotherapy drugs, including cisplatin $(22,23)$. In the present study, a NSCLC cell clone, A549, was chosen as a cell model to evaluate the sensitivity/resistance of lung cancer cells to cisplatin. Notably, serial passages of A549 cells under $1-2 \mu \mathrm{M}$ cisplatin treatment gave rise to the cisplatin-resistant phenotype of A549 cells. A549 colonies with a larger size were manually enriched via colony forming assay. The results of growth curve, colony formation and migration assays confirmed that the A549R cells with the cisplatin-resistant phenotype grew and migrated more efficiently under cisplatin treatment than wild-type A549 cells. In addition, cisplatin-induced apoptosis was significantly 
Table II. Proteins with >1.5-fold change $(\mathrm{L} / \mathrm{H})$ in expression levels in A549R cells when compared with A549 cells.

\begin{tabular}{|c|c|c|c|c|}
\hline Accession no. & Uniprot ID & Protein name & Fold (L/H) & GO term name biological pathway \\
\hline $\mathrm{P} 11021^{*}$ & GRP78 & $\begin{array}{l}78 \mathrm{kDa} \text { glucose-regulated } \\
\text { protein (bip) }\end{array}$ & 2.87 & $\begin{array}{l}\text { Anti-apoptosis, calcium ion binding, enzyme } \\
\text { binding, misfolded protein binding }\end{array}$ \\
\hline $\mathrm{P} 43246^{*}$ & MSH2 & $\begin{array}{l}\text { DNA mismatch repair protein } \\
\text { Msh2 (hmsh2) }\end{array}$ & 2.75 & $\begin{array}{l}\text { Mismatch repair, intrinsic apoptotic } \\
\text { signaling pathway in response to DNA } \\
\text { damage by p53 class mediator }\end{array}$ \\
\hline P26599* & PTBP1 & $\begin{array}{l}\text { Polypyrimidine tract-binding } \\
\text { protein } 1 \text { (hnRNP I) }\end{array}$ & 2.7 & $\begin{array}{l}\text { mRNA processing, mRNA splicing, } \\
\text { via spliceosome }\end{array}$ \\
\hline P07339* & CATD & Cathepsin D & 2.67 & $\begin{array}{l}\text { Autophagic vacuole assembly, protein } \\
\text { catabolic process, proteolysis }\end{array}$ \\
\hline Q8NBS9* & TXND5 & $\begin{array}{l}\text { Thioredoxin domain- } \\
\text { containing protein } 5\end{array}$ & 2.6 & $\begin{array}{l}\text { Anti-apoptosis, protein folding, response } \\
\text { to endoplasmic reticulum stress }\end{array}$ \\
\hline P13693* & TCTP & $\begin{array}{l}\text { Translationally-controlled } \\
\text { tumor protein (TCTP) }\end{array}$ & 2.58 & Anti-apoptosis in response to DNA damage \\
\hline Q9Y3F4 & STRAP & $\begin{array}{l}\text { Serine-threonine kinase } \\
\text { receptor-associated protein }\end{array}$ & 2.52 & $\begin{array}{l}\text { mRNA processing, negative regulation of } \\
\text { pathway-restricted SMAD protein phosphorylation }\end{array}$ \\
\hline Q9UMS4* & PRP19 & Pre-mRNA-processing factor 19 & 2.46 & DNA repair, ubiquitin-ubiquitin ligase activity \\
\hline P61224 & RAP1B & Ras-related protein Rap- $1 b$ & 2.03 & $\begin{array}{l}\text { Cell proliferation, positive regulation } \\
\text { of ERK } 1 \text { and ERK } 2 \text { cascade }\end{array}$ \\
\hline P08107* & HSP71 & $\begin{array}{l}\text { Heat shock } 70 \mathrm{kDa} \\
\text { protein } 1 \mathrm{~A} / 1 \mathrm{~B}\end{array}$ & 1.89 & $\begin{array}{l}\text { Anti-apoptosis, cellular response to oxidative } \\
\text { stress, negative regulation of cell death }\end{array}$ \\
\hline P52701* & MSH6 & $\begin{array}{l}\text { DNA mismatch repair } \\
\text { protein Msh6 (hmsh6) }\end{array}$ & 1.76 & $\begin{array}{l}\text { DNA damage response, methylated histone } \\
\text { binding, mismatched DNA binding }\end{array}$ \\
\hline $\mathrm{P} 09525^{*}$ & ANXA4 & Annexin A4 (Annexin IV) & 1.73 & $\begin{array}{l}\text { Anti-apoptosis, negative regulation of } \mathrm{NF}-\kappa \mathrm{B} \\
\text { transcription factor activity }\end{array}$ \\
\hline P99999* & CYC & Cytochrome $\mathrm{C}$ & 1.72 & $\begin{array}{l}\text { Cellular respiration, cellular response to oxidative } \\
\text { stress, intrinsic apoptotic signaling pathway }\end{array}$ \\
\hline P62714* & $\mathrm{PP} 2 \mathrm{AB}$ & $\begin{array}{l}\text { Serine/threonine-protein } \\
\text { phosphatase } 2 \mathrm{~A} \text { catalytic } \\
\text { subunit } \beta \text { isoform }(\mathrm{PP} 2 \mathrm{~A}-\beta)\end{array}$ & 1.69 & $\begin{array}{l}\text { Protein amino acid dephosphorylation, } \\
\text { apoptotic mitochondrial changes, } \\
\text { negative regulation of Ras protein signal, } \\
\text { response to endoplasmic reticulum stress }\end{array}$ \\
\hline P52565* & GDIR1 & $\begin{array}{l}\text { Rho GDP-dissociation } \\
\text { inhibitor } 1 \text { (Rho GDI 1) }\end{array}$ & 1.67 & $\begin{array}{l}\text { Anti-apoptosis, regulation of Rho protein } \\
\text { signal transduction and of small GTPase } \\
\text { mediated signal transduction }\end{array}$ \\
\hline Q01130 & SFRS2 & $\begin{array}{l}\text { Serine/arginine-rich splicing } \\
\text { factor } 2 \text { (Protein PR264) }\end{array}$ & 1.58 & $\begin{array}{l}\text { mRNA processing, mitotic cell cycle, } \\
\text { mRNA export from nucleus }\end{array}$ \\
\hline $\mathrm{P} 07355^{*}$ & ANXA2 & Annexin A2 (Annexin II) & 1.53 & $\begin{array}{l}\text { Skeletal system development, } \\
\text { phosphatidylinositol-4,5-bisphosphate binding, } \\
\text { phospholipase A2 inhibitor activity }\end{array}$ \\
\hline Q9P287* & BCCIP & $\begin{array}{l}\text { BRCA2 and CDKN1A- } \\
\text { interacting protein }\end{array}$ & 1.51 & $\begin{array}{l}\text { DNA repair, regulation of cyclin-dependent } \\
\text { protein serine/threonine kinase activity }\end{array}$ \\
\hline O00194 & RB27B & Ras-related protein Rab-27B & 0.66 & $\begin{array}{l}\text { GTP binding, myosin V binding, protein } \\
\text { domain specific binding }\end{array}$ \\
\hline Q0WX57* & U17LO & $\begin{array}{l}\text { Ubiquitin-specific-17 } \\
\text { processing protease }\end{array}$ & 0.66 & $\begin{array}{l}\text { Apoptotic process, protein deubiquitination } \\
\text { involved in ubiquitin-dependent protein } \\
\text { catabolic process }\end{array}$ \\
\hline O94804 & STK10 & $\begin{array}{l}\text { Serine/threonine-protein } \\
\text { kinase } 10\end{array}$ & 0.64 & $\begin{array}{l}\text { Regulation of apoptotic process, regulation of } \\
\text { mitotic cell cycle, signal transduction } \\
\text { by protein phosphorylation }\end{array}$ \\
\hline
\end{tabular}


Table II. Continued.

\begin{tabular}{|c|c|c|c|c|}
\hline Accession no. & Uniprot ID & Protein name & Fold $(\mathrm{L} / \mathrm{H})$ & GO term name biological pathway \\
\hline O60656 & UD19 & UDP-glucuronosyltransferase 1-9 & 0.62 & $\begin{array}{l}\text { Glucuronosyltransferase activity, negative } \\
\text { regulation of cellular glucuronidation }\end{array}$ \\
\hline Q16513* & PKN2 & $\begin{array}{l}\text { Serine/threonine-protein } \\
\text { kinase N2 }\end{array}$ & 0.62 & $\begin{array}{l}\text { Apoptotic process, cell adhesion, } \\
\text { cell cycle and cell division }\end{array}$ \\
\hline Q16222 & UAP1 & $\begin{array}{l}\text { UDP-N-acetylhexosamine } \\
\text { pyrophosphorylase }\end{array}$ & 0.6 & $\begin{array}{l}\text { Carbohydrate binding, UDP- } \\
\text { N-acetylglucosamine diphosphorylase activity }\end{array}$ \\
\hline Q16539 & MK14 & $\begin{array}{l}\text { Mitogen-activated } \\
\text { protein kinase } 14\end{array}$ & 0.59 & $\begin{array}{l}\text { Apoptotic process, DNA damage checkpoint, } \\
\text { intracellular signal transduction }\end{array}$ \\
\hline P62308 & RUXG & $\begin{array}{l}\text { Small nuclear } \\
\text { ribonucleoprotein } \mathrm{G}\end{array}$ & 0.58 & $\begin{array}{l}\text { RNA binding, histone mRNA metabolic process, } \\
\text { mRNA splicing, RNA splicing }\end{array}$ \\
\hline Q07812 & BAX & Apoptosis regulator BAX & 0.58 & $\begin{array}{l}\text { Apoptotic mitochondrial changes, } \\
\text { apoptotic process, DNA damage response }\end{array}$ \\
\hline Q9NZJ7* & MTCH1 & $\begin{array}{l}\text { Mitochondrial carrier } \\
\text { homolog } 1\end{array}$ & 0.56 & $\begin{array}{l}\text { Activation of cysteine-type endopeptidase } \\
\text { activity, apoptotic process }\end{array}$ \\
\hline Q15464* & SHB & $\begin{array}{l}\text { SH2 domain-containing } \\
\text { adapter protein B }\end{array}$ & 0.55 & $\begin{array}{l}\text { Apoptotic process, cell differentiation, } \\
\text { SH3/SH2 adaptor activity }\end{array}$ \\
\hline O14763* & TR10B & TRAIL receptor 2 & 0.53 & $\begin{array}{l}\text { Receptor for the cytotoxic ligand } \\
\text { TNFSF10/TRAIL, the adapter molecule FADD } \\
\text { recruits caspase- } 8 \text { to the activated receptor }\end{array}$ \\
\hline Q16890 & TPD53 & Tumor protein D53 & 0.49 & $\begin{array}{l}\text { G2/M transition of mitotic cell cycle source, } \\
\text { positive regulation of apoptotic signaling } \\
\text { pathway and of JNK cascade }\end{array}$ \\
\hline Q9H4P4 & RNF41 & $\begin{array}{l}\text { E3 ubiquitin-protein } \\
\text { ligase NRDP1 }\end{array}$ & 0.47 & $\begin{array}{l}\text { Autophagy, extrinsic apoptotic signaling } \\
\text { pathway, negative regulation of cell proliferation }\end{array}$ \\
\hline
\end{tabular}

Accession numbers marked with an asterisks $\left(^{*}\right)$ are those that are affected by either up- or downregulation. GO, Gene Ontology; $\mathrm{H}$, heavy-labeled; L, light-labeled.

decreased in A549R cells when compared with A549 cells. Taken together, A549R cells were less responsive to cisplatin.

Marked improvements have been achieved in the past few decades in our understanding of lung cancer biology $(24,25)$. The identification of driver oncogenes in lung cancers has led to a change in cancer treatments. Some studies have provided greater understanding regarding the mechanisms underlying chemotherapy sensitivity/resistance and the associated biomarkers of lung cancer (26-30). Deregulated mesenchymal-epithelial transition (31) and reduced apoptosis induction (32) have been indicated to underlie the chemoresistance in lung cancer. Autophagy is a self-protective mechanism to guarantee basic energy supply under nutrition-deficient conditions, such as starvation (33). The cytoprotective mechanism of autophagy against chemotherapy has also been recognized in lung cancer cells (33) and other types of cancers $(9,15,34,35)$. Thus, autophagy has been highlighted as one of the mechanisms underlying the chemoresistance of NSCLC. In the present study, autophagy induction by cisplatin was observed in A549 and A549R cells, and could be inhibited by the autophagy inhibitor, 3MA. Notably, a significantly higher level of autophagy was observed in A549R cells when compared with A549 cells. This implies that autophagy may contribute to the cisplatin-resistance phenotype of A549R cells.

Proteomics has been widely utilized to profile, screen and identify specific phenotype- or genotype-associated biomarkers $(36,37)$. In recent years, SILAC has stood out when distinguishing the proteomics from one group to another, such as in cancer biomarker discovery $(11,13)$ and in the identification of chemoresistance-associated biomarkers (16). In the present study, two rounds of SILAC procedures were performed with paired groups of H-labeled A549R cells and L-labeled A549 cells, or with paired groups of L-labeled A549R cells and H-labeled A549 cells. A total of $1,161 \pm 152$ quantitative peptides and $357 \pm 36$ proteins were induced by cisplatin $(10 \mu \mathrm{M})$ between A549R and A549 cells. A total of $344 \pm 21$ proteins were confirmed by two or more peptides. In addition, among the 23 proteins with 1.5 -fold greater expression in the $\mathrm{H}$-labeled A549R cells and the 18 proteins with 1.5 -fold greater expression in the L-labeled A549R cells, there were 15 proteins that were repeated in the 2 rounds of experiments. On the other hand, there were 17 and 15 proteins that were downregulated in $\mathrm{H}$ - and L-labeled A549R cells, respectively. Particularly, the downregulation of apoptosis-associated proteins, including TR10B, U17LO, 
Table III. Involvement of upregulated proteins in anti-apoptosis and autophagy promotion in human lung cancer and other types of cells.

\begin{tabular}{|c|c|c|c|c|c|c|}
\hline \multirow[b]{2}{*}{ UniProt ID } & \multicolumn{3}{|c|}{ Anti-apoptosis } & \multicolumn{3}{|c|}{ Autophagy promotion } \\
\hline & Author, year & Cell type & Ref. & Author, year & Cell type & Ref. \\
\hline GRP78 & $\begin{array}{l}\text { Sun et al, 2012; } \\
\text { Ahmad et al, } 2014\end{array}$ & Lung cancer & $(28,29)$ & $\begin{array}{l}\text { Kim et al, 2012; } \\
\text { Xie et al, } 2016\end{array}$ & Lung cancer & $(27,46)$ \\
\hline PRP19 & Lu et al, 2007 & Other & $(39)$ & - & NR & / \\
\hline ТСТР & $\begin{array}{l}\text { Du et al, 2017; } \\
\text { Rho et al, } 2011\end{array}$ & Lung cancer & $(26,43)$ & $\begin{array}{l}\text { Chen et al, 2014; } \\
\text { Bonhoure et al, } 2017\end{array}$ & Other & $(44,47)$ \\
\hline HSP71 & Tian et al, 2013 & Other & $(45)$ & - & NR & / \\
\hline PTBP1 & Takai et al, 2017 & Other & $(48)$ & Li et al, 2016; Takai et al, 2017 & Other & $(33,48)$ \\
\hline CATD & $\begin{array}{l}\text { Wille et al, 2004; } \\
\text { Li et al, } 2004\end{array}$ & Lung cancer & $(37,49)$ & $\begin{array}{l}\text { Oliveira et al, 2015; } \\
\text { Hah et al, } 2012\end{array}$ & Other & $(50,51)$ \\
\hline CYC & $\begin{array}{l}\text { Chen et al, 2015; } \\
\text { Moravcikova et al, 2014; } \\
\text { Lee et al, } 2015\end{array}$ & Lung cancer & $(52-54)$ & $\begin{array}{l}\text { Li et al, 2016; } \\
\text { Kaminskyy et al, } 2012\end{array}$ & Lung cancer & $(38,55)$ \\
\hline TXND5 & Lee et al, 2010 & Other & (34) & - & NR & l \\
\hline MSH6 & $\begin{array}{l}\text { Yu et al, 2017; } \\
\text { Habiel et al, } 2017\end{array}$ & Lung cancer & $(30,56)$ & $\begin{array}{l}\text { Knizhnik et al, 2013; } \\
\text { Zanotto-Filo et al, } 2015\end{array}$ & Other & $(40,57)$ \\
\hline ANXA2 & $\begin{array}{l}\text { Dassah et al, 2014; } \\
\text { Wang et al, } 2017\end{array}$ & Lung cancer & $(36,58)$ & $\begin{array}{l}\text { Wang et al, 2017; } \\
\text { Chen et al, } 2017\end{array}$ & Lung cancer & $(58,59)$ \\
\hline BCCIP & Xu et al, 2017 & Lung cancer & $(60)$ & - & NR & / \\
\hline MSH2 & $\begin{array}{l}\text { Zhang et al, 2016; } \\
\text { Terry et al, } 2015\end{array}$ & Lung cancer & $(41,61)$ & $\begin{array}{l}\text { Zeng et al, 2007; } \\
\text { Zeng et al, } 2007\end{array}$ & Other & $(42,62)$ \\
\hline PP2AB & $\begin{array}{l}\text { Huang et al, 2004; } \\
\text { Shtrichman et al, } 2000\end{array}$ & Other & $(63,64)$ & $\begin{array}{l}\text { Banreti et al, 2012; } \\
\text { Ogura et al, } 2010\end{array}$ & Other & $(65,66)$ \\
\hline GDIR1 & - & NR & l & - & NR & l \\
\hline ANXA4 & $\begin{array}{l}\text { Yao et al, 2016; } \\
\text { Nagappan et al, } 2016\end{array}$ & Lung cancer & $(67,68)$ & - & NR & / \\
\hline
\end{tabular}

'Other', indicates different types of cells to lung cancer cells; NR, not reported; GRP78, glucose-regulated protein, 78 kDa; HSP71, heat shock protein 71; PRP19, pre-mRNA processing factor 19; PTBP1, polypyrimidine tract binding protein 1; TCTP, translationally controlled tumor protein; CATD, Cathepsin D; CYC, Cytochrome $c$; TXND5, thioredoxin domain containing 5; MSH2/6, MutS homolog 2/6; ANXA2/4, Annexin A2/4; BCCIP, RCA2 and Cyclin dependent kinase inhibitor $1 \mathrm{~A}$ interacting protein; PP2AB, protein phosphatase 2A 55 kDa regulatory subunit B $\alpha$; GDIR1, Rho glyceraldehyde-3-phosphate-dissociation inhibitor 1.

SHB, PKN2 and MTCH1, was observed in the two types of labeling experiments. These downregulated proteins may be involved in mitochondrial dysfunction, the cell response to stress, nuclear acid damage and finally in apoptosis induction. Exposure of any of the two proapoptotic domains of MTCH1 on the surface of mitochondria is sufficient for the induction of apoptosis in a B-cell lymphoma-2 (Bcl-2)-associated $\mathrm{X} / \mathrm{Bcl}-2$ antagonist/killer-independent manner (38). SH2 domain-containing adapter protein B (SHB) has been indicated to be involved in the Fyn related Src family tyrosine kinase-SHB signaling pathway, and regulates cell survival, differentiation and proliferation (39). The possible roles of U17LO, PKN2 and TR10B were not clear up until now.

$\mathrm{GO}$ analysis indicated that the majority of the proteins regulated apoptosis $(26,28,29,40-43)$, DNA damage repairing (43-46) and other biological pathways. The effect of anti-apoptosis and autophagy promotion was also identified for these proteins in human lung cancer cells and other types of cells. GRP78 antagonizes apoptosis and positively regulates autophagy in human NSCLC cells via the adenosine monophosphate-activated protein kinase-mammalian target of rapamycin signaling pathway $(28,29)$. TCTP also inhibits apoptosis by binding to p53 in lung carcinoma cells $(26,47,48)$. The anti-apoptosis effect of HSP71 was also recognized in azacytidine-treated myeloma cells (49). Given the importance of anti-apoptosis and autophagy in chemotherapy resistance in cancer, the present study summarized the involvement of all of the 15 upregulated proteins in $\mathrm{H}$ - and L-labeled A549R cells in anti-apoptosis and/or autophagy promotion (Table III). It was indicated that the majority of these proteins were closely associated with anti-apoptosis and/or autophagy promotion in lung cancers or in other types of cancers. In addition, the majority of proteins that directly regulate autophagy were upregulated by $<1.5$-fold, though autophagy was significantly 
different in the two groups of A549 cells, which may be due to the difference in sensitivity among SILAC and other methods.

However, the detailed signaling pathways underlying such chemoresistance in A549R cells were not clear. In particular, though proteins such as GRP78, HSP71, PRP19, PTBP1, TCTP, CATD, CYC, TXND5, MSH6, ANXA2, BCCIP, MSH2, PP2AB, GDIR1 and ANXA4 were significantly deregulated in A549R cells, the association of each molecule with autophagy or directly with chemoresistance requires further investigation.

In conclusion, the present study isolated a cisplatin-resistant human lung cancer A549 cell clone, with reduced apoptosis and high levels of autophagy, in response to cisplatin treatment. SILAC proteomics recognized the high expression of GRP78 and other proteins that were associated with anti-apoptosis and/or autophagy promotion in cisplatin-resistant A549R cells.

\section{Acknowledgements}

Not applicable.

\section{Funding}

The present study was supported by grants from the National Nature Science Foundation of China (grant no. 80151459), the Development Project from Science and Technology Department of Jilin Province (grant no. 140520020JH) and the Thirteen Five Science and Technology Research Project of Jilin Province Department of Education (grant no. 2016-467).

\section{Availability of data and materials}

The datasets used and/or analyzed during the current study are available from the corresponding author on reasonable request.

\section{Authors' contributions}

ZW and GL designed the experiments. ZW, GL and JJ performed the experiments. ZW conducted the statistical analysis. GL wrote the manuscript. All authors have read and approved the final manuscript.

\section{Ethics approval and consent to participate}

Not applicable.

\section{Patient consent for publication}

Not applicable.

\section{Competing interests}

The authors declare that they have no competing interests.

\section{References}

1. Fidler MM, Soerjomataram I and Bray F: A global view on cancer incidence and national levels of the human development index. Int J Cancer 139: 2436-2446, 2016.

2. Shen C, Wang X, Tian L, Zhou Y, Chen D, Du H, Wang W, Liu L and Che G: 'Different trend' in multiple primary lung cancer and intrapulmonary metastasis. Eur J Med Res 20: 17, 2015.
3. Kalemkerian GP: Advances in pharmacotherapy of small cell lung cancer. Expert Opin Pharmacother 15: 2385-2396, 2014.

4. Scagliotti GV, Parikh P, von Pawel J, Biesma B, Vansteenkiste J, Manegold C, Serwatowski P, Gatzemeier U, Digumarti R, Zukin M, et al: Phase III study comparing cisplatin plus gemcitabine with cisplatin plus pemetrexed in chemotherapy-naive patients with advanced-stage non-small-cell lung cancer. J Clin Oncol 26: 3543-3551, 2008.

5. Socinski MA, Smit EF, Lorigan P, Konduri K, Reck M, Szczesna A, Blakely J, Serwatowski P, Karaseva NA, Ciuleanu T, et al: Phase III study of pemetrexed plus carboplatin compared with etoposide plus carboplatin in chemotherapy-naive patients with extensive-stage small-cell lung cancer. J Clin Oncol 27: 4787-4792, 2009.

6. Kim ES: Chemotherapy resistance in lung cancer. Adv Exp Med Biol 893: 189-209, 2016

7. Willers H, Azzoli CG, Santivasi WL and Xia F: Basic mechanisms of therapeutic resistance to radiation and chemotherapy in lung cancer. Cancer J 19: 200-207, 2013.

8. Zembutsu H, Ohnishi Y, Tsunoda T, Furukawa Y, Katagiri T, Ueyama Y, Tamaoki N, Nomura T, Kitahara O, Yanagawa R, et al: Genome-wide cDNA microarray screening to correlate gene expression profiles with sensitivity of 85 human cancer xenografts to anticancer drugs. Cancer Res 62: 518-527, 2002.

9. Kihara C, Tsunoda T, Tanaka T, Yamana H, Furukawa Y, Ono K, Kitahara O, Zembutsu H, Yanagawa R, Hirata K, et al: Prediction of sensitivity of esophageal tumors to adjuvant chemotherapy by cDNA microarray analysis of gene-expression profiles. Cancer Res 61: 6474-6479, 2001.

10. Beltran H, Yelensky R, Frampton GM, Park K, Downing SR, MacDonald TY, Jarosz M, Lipson D, Tagawa ST, Nanus DM, et al: Targeted next-generation sequencing of advanced prostate cancer identifies potential therapeutic targets and disease heterogeneity. Eur Urol 63: 920-926, 2013.

11. Hoedt E, Zhang G and Neubert TA: Stable isotope labeling by amino acids in cell culture (SILAC) for quantitative proteomics. Adv Exp Med Biol 806: 93-106, 2014.

12. Patella F, Neilson LJ, Athineos D, Erami Z, Anderson KI, Blyth K, Ryan KM and Zanivan S: In-depth proteomics identifies a role for autophagy in controlling reactive oxygen species mediated endothelial permeability. J Proteome Res 15: 2187-2197, 2016.

13. Lanucara F and Eyers CE: Mass spectrometric-based quantitative proteomics using SILAC. Methods Enzymol 500: 133-150, 2011.

14. Yeh CC, Hsu CH, Shao YY, Ho WC, Tsai MH, Feng WC and Chow LP: Integrated stable isotope labeling by amino acids in cell culture (SILAC) and isobaric tags for relative and absolute quantitation (iTRAQ) quantitative proteomic analysis identifies galectin-1 as a potential biomarker for predicting dorafenib resistance in liver cancer. Mol Cell Proteomics 14: 1527-1545, 2015.

15. Wu X, Zahari MS, Renuse S, Nirujogi RS, Kim MS, Manda SS, Stearns V, Gabrielson E, Sukumar S and Pandey A: Phosphoproteomic analysisidentifies focal adhesion kinase2 (FAK2) as a potential therapeutic target for tamoxifen resistance in breast cancer. Mol Cell Proteomics 14: 2887-2900, 2015.

16. Xu H, Dephoure N, Sun H, Zhang H, Fan F, Liu J, Ning X, Dai S, Liu B, Gao M, et al: Proteomic profiling of paclitaxel treated cells identifies a novel mechanism of drug resistance mediated by PDCD4. J Proteome Res 14: 2480-2491, 2015.

17. Bosse K, Haneder S, Arlt C, Ihling CH, Seufferlein T and Sinz A: Mass spectrometry-based secretome analysis of non-small cell lung cancer cell lines. Proteomics 16: 2801-2814, 2016.

18. Sun P, Feng LX, Zhang DM, Liu M, Liu W, Mi T, Wu WY, Jiang BH, Yang M, Hu LH, et al: Bufalin derivative BF211 inhibits proteasome activity in human lung cancer cells in vitro by inhibiting $\beta 1$ subunit expression and disrupting proteasome assembly. Acta Pharmacol Sin 37: 908-918, 2016.

19. Liu G, Pei F, Yang F, Li L, Amin AD, Liu S, Buchan JR and Cho WC: Role of autophagy and apoptosis in non-small-cell lung cancer. Int J Mol Sci 18: 18, 2017.

20. Lee JG, Shin JH, Shim HS, Lee CY, Kim DJ, Kim YS and Chung KY: Autophagy contributes to the chemo-resistance of non-small cell lung cancer in hypoxic conditions. Respir Res 16: $138,2015$.

21. Liu M, Ma S, Liu M, Hou Y, Liang B, Su X and Liu X: Synergistic killing of lung cancer cells by cisplatin and radiation via autophagy and apoptosis. Oncol Lett 7: 1903-1910, 2014. 
22. Pisters KM, Evans WK, Azzoli CG, Kris MG, Smith CA, Desch CE, Somerfield MR, Brouwers MC, Darling G, Ellis PM, et al; Cancer Care Ontario; American Society of Clinical Oncology: Cancer Care Ontario and American Society of Clinical Oncology adjuvant chemotherapy and adjuvant radiation therapy for stages I-IIIA resectable non small-cell lung cancer guideline. J Clin Oncol 25: 5506-5518, 2007.

23. Paz-Ares L, Mezger J, Ciuleanu TE, Fischer JR, von Pawel J, Provencio M, Kazarnowicz A, Losonczy G, de Castro G Jr, Szczesna A, et al; INSPIRE investigators: Necitumumab plus pemetrexed and cisplatin as first-line therapy in patients with stage IV non-squamous non-small-cell lung cancer (INSPIRE): An open-label, randomised, controlled phase 3 study. Lancet Oncol 16: 328-337, 2015.

24. Lemjabbar-Alaoui H, Hassan OU, Yang YW and Buchanan P. Lung cancer: Biology and treatment options. Biochim Biophys Acta 1856: 189-210, 2015.

25. Sánchez-Céspedes M: Lung cancer biology: A genetic and genomic perspective. Clin Transl Oncol 11: 263-269, 2009.

26. Du J, Yang P, Kong F and Liu H: Aberrant expression of translationally controlled tumor protein (TCTP) can lead to radioactive susceptibility and chemosensitivity in lung cancer cells. Oncotarget 8: 101922-101935, 2017.

27. Kim KM, Yu TK, Chu HH, Park HS, Jang KY, Moon WS, Kang MJ, Lee DG, Kim MH, Lee JH, et al: Expression of ER stress and autophagy-related molecules in human non-small cell lung cancer and premalignant lesions. Int J Cancer 131: E362-E370, 2012.

28. Sun Q, Hua J, Wang Q, Xu W, Zhang J, Zhang J, Kang J and Li M: Expressions of GRP78 and Bax associate with differentiation, metastasis, and apoptosis in non-small cell lung cancer. Mol Biol Rep 39: 6753-6761, 2012.

29. Ahmad M, Hahn IF and Chatterjee S: GRP78 up-regulation leads to hypersensitization to cisplatin in A549 lung cancer cells. Anticancer Res 34: 3493-3500, 2014.

30. Yu W, Lu W, Chen G, Cheng F, Su H, Chen Y, Liu M and Pang X: Inhibition of histone deacetylases sensitizes EGF receptor-TK inhibitor-resistant non-small-cell lung cancer cells to erlotinib in vitro and in vivo. Br J Pharmacol 174: 3608-3622, 2017.

31. Mortimore GE, Miotto G, Venerando R and Kadowaki M: Autophagy. Subcell Biochem 27: 93-135, 1996.

32. Notte A, Ninane N, Arnould T and Michiels C: Hypoxia counteracts taxol-induced apoptosis in MDA-MB-231 breast cancer cells: Role of autophagy and JNK activation. Cell Death Dis 4: e638, 2013

33. Li C, Zhao Z, Zhou Z and Liu R: Linc-ROR confers gemcitabine resistance to pancreatic cancer cells via inducing autophagy and modulating the miR-124/PTBP1/PKM2 axis. Cancer Chemother Pharmacol 78: 1199-1207, 2016.

34. Lee WL, Wen TN, Shiau JY and Shyur LF: Differential proteomic profiling identifies novel molecular targets of paclitaxel and phytoagent deoxyelephantopin against mammary adenocarcinoma cells. J Proteome Res 9: 237-253, 2010.

35. Liang S, Xu Z, Xu X, Zhao X, Huang C and Wei Y: Quantitative proteomics for cancer biomarker discovery. Comb Chem High Throughput Screen 15: 221-231, 2012.

36. Dassah M, Almeida D, Hahn R, Bonaldo P, Worgall S and Hajjar KA: Annexin A2 mediates secretion of collagen VI, pulmonary elasticity and apoptosis of bronchial epithelial cells. J Cell Sci 127: 828-844, 2014.

37. Wille A, Gerber A, Heimburg A, Reisenauer A, Peters C, Saftig P, Reinheckel T, Welte T and Bühling F: Cathepsin L is involved in cathepsin D processing and regulation of apoptosis in A549 human lung epithelial cells. Biol Chem 385: 665-670, 2004.

38. Li YR, Li S, Ho CT, Chang YH, Tan KT, Chung TW, Wang BY, Chen YK and Lin CC: Tangeretin derivative, 5-acetyloxy-6,7,8,4'-tetramethoxyflavone induces G2/M arrest, apoptosis and autophagy in human non-small cell lung cancer cells in vitro and in vivo. Cancer Biol Ther 17: 48-64, 2016.

39. Lu X and Legerski RJ: The Prp19/Pso4 core complex undergoes ubiquitylation and structural alterations in response to DNA damage. Biochem Biophys Res Commun 354: 968-974, 2007.

40. Knizhnik AV, Roos WP, Nikolova T, Quiros S, Tomaszowski KH, Christmann M and Kaina B: Survival and death strategies in glioma cells: Autophagy, senescence and apoptosis triggered by a single type of temozolomide-induced DNA damage. PLoS One 8: e55665, 2013.

41. Zhang M, Hu C, Tong D, Xiang S, Williams K, Bai W, Li GM, Bepler $\mathrm{G}$ and Zhang X: Ubiquitin-specific peptidase 10 (USP10) deubiquitinates and stabilizes MutS homolog 2 (MSH2) to regulate cellular sensitivity to DNA damage. J Biol Chem 291: 10783-10791, 2016.
42. Zeng $X$ and Kinsella TJ: A novel role for DNA mismatch repair and the autophagic processing of chemotherapy drugs in human tumor cells. Autophagy 3: 368-370, 2007.

43. Rho SB, Lee JH, Park MS, Byun HJ, Kang S, Seo SS, Kim JY and Park SY: Anti-apoptotic protein TCTP controls the stability of the tumor suppressor p53. FEBS Lett 585: 29-35, 2011.

44. Chen K, Huang C, Yuan J, Cheng H and Zhou R: Long-term artificial selection reveals a role of TCTP in autophagy in mammalian cells. Mol Biol Evol 31: 2194-2211, 2014.

45. Tian E, Tang H, Xu R, Liu C, Deng H and Wang Q: Azacytidine induces necrosis of multiple myeloma cells through oxidative stress. Proteome Sci 11: 24, 2013.

46. Xie WY, Zhou XD, Yang J, Chen LX and Ran DH: Inhibition of autophagy enhances heat-induced apoptosis in human non-small cell lung cancer cells through ER stress pathways. Arch Biochem Biophys 607: 55-66, 2016.

47. Bonhoure A, Vallentin A, Martin M, Senff-Ribeiro A, Amson R, Telerman A and Vidal M: Acetylation of translationally controlled tumor protein promotes its degradation through chaperone-mediated autophagy. Eur J Cell Biol 96: 83-98, 2017.

48. Takai T, Yoshikawa Y, Inamoto T, Minami K, Taniguchi K, Sugito N, Kuranaga Y, Shinohara H, Kumazaki M, Tsujino T, et al: A Novel combination RNAi toward Warburg effect by replacement with miR-145 and silencing of PTBP1 induces apoptotic cell death in bladder cancer cells. Int J Mol Sci 18: 18, 2017.

49. Li X, Rayford H, Shu R, Zhuang J and Uhal BD: Essential role for cathepsin D in bleomycin-induced apoptosis of alveolar epithelial cells. Am J Physiol Lung Cell Mol Physiol 287: L46-L51, 2004.

50. Oliveira CS, Pereira H, Alves S, Castro L, Baltazar F, Chaves SR, Preto A and Côrte-Real M: Cathepsin D protects colorectal cancer cells from acetate-induced apoptosis through autophagy-independent degradation of damaged mitochondria. Cell Death Dis 6: e1788, 2015.

51. Hah YS, Noh HS, Ha JH, Ahn JS, Hahm JR, Cho HY and Kim DR: Cathepsin D inhibits oxidative stress-induced cell death via activation of autophagy in cancer cells. Cancer Lett 323: 208-214, 2012

52. Chen H, Liang ZW, Wang ZH, Zhang JP, Hu B, Xing XB and Cai WB: Akt activation and inhibition of cytochrome $\mathrm{C}$ release: mechanistic insights into leptin-promoted survival of type II Alveolar Epithelial Cells. J Cell Biochem 116: 2313-2324, 2015.

53. Moravcikova E, Krepela E, Prochazka J, Benkova K and Pauk N: Differential sensitivity to apoptosome apparatus activation in non-small cell lung carcinoma and the lung. Int $\mathrm{J}$ Oncol 44: 1443-1454, 2014.

54. Lee J, Yeganeh B, Ermini L and Post M: Sphingolipids as cell fate regulators in lung development and disease. Apoptosis 20: 740-757, 2015.

55. Kaminskyy VO, Piskunova T, Zborovskaya IB, Tchevkina EM and Zhivotovsky B: Suppression of basal autophagy reduces lung cancer cell proliferation and enhances caspase-dependent and -independent apoptosis by stimulating ROS formation. Autophagy 8: 1032-1044, 2012.

56. Habiel DM, Camelo A, Espindola M, Burwell T, Hanna R, Miranda E, Carruthers A, Bell M, Coelho AL, Liu H, et al: Divergent roles for clusterin in lung injury and repair. Sci Rep 7: $15444,2017$.

57. Zanotto-Filho A, Braganhol E, Klafke K, Figueiró F, Terra SR, Paludo FJ, Morrone M, Bristot IJ, Battastini AM, Forcelini CM, et al: Autophagy inhibition improves the efficacy of curcumin/temozolomide combination therapy in glioblastomas. Cancer Lett 358: 220-231, 2015.

58. Wang K, Zhang T, Lei Y, Li X, Jiang J, Lan J, Liu Y, Chen H, Gao W, Xie N, et al: Identification of ANXA2 (annexin A2) as a specific bleomycin target to induce pulmonary fibrosis by impeding TFEB-mediated autophagic flux. Autophagy 14: 269-282, 2018

59. Chen YD, Fang YT, Cheng YL, Lin CF, Hsu LJ, Wang SY, Anderson R, Chang CP and Lin YS: Exophagy of annexin A2 via RAB11, RAB8A and RAB27A in IFN- $\gamma$-stimulated lung epithelial cells. Sci Rep 7: 5676, 2017.

60. Xu XT, Hu WT, Zhou JY and Tu Y: Celecoxib enhances the radiosensitivity of HCT116 cells in a COX-2 independent manner by up-regulating BCCIP. Am J Transl Res 9: 1088-1100, 2017.

61. Terry MR, Arya R, Mukhopadhyay A, Berrett KC, Clair PM, Witt B, Salama ME, Bhutkar A and Oliver TG: Caspase-2 impacts lung tumorigenesis and chemotherapy response in vivo. Cell Death Differ 22: 719-730, 2015 
62. Zeng X, Yan T, Schupp JE, Seo Y and Kinsella TJ: DNA mismatch repair initiates 6-thioguanine - induced autophagy through p53 activation in human tumor cells. Clin Cancer Res 13: 1315-1321, 2007.

63. Huang S, Shu L, Easton J, Harwood FC, Germain GS, Ichijo H and Houghton PJ: Inhibition of mammalian target of rapamycin activates apoptosis signal-regulating kinase 1 signaling by suppressing protein phosphatase 5 activity. J Biol Chem 279: 36490-36496, 2004

64. Shtrichman R, Sharf R and Kleinberger T: Adenovirus E4orf4 protein interacts with both Balpha and B' subunits of protein phosphatase 2A, but E4orf4-induced apoptosis is mediated only by the interaction with Balpha. Oncogene 19: 3757-3765, 2000.

65. Bánréti Á, Lukácsovich T, Csikós G, Erdélyi M and Sass M: PP2A regulates autophagy in two alternative ways in Drosophila. Autophagy 8: 623-636, 2012.
66. Ogura K, Okada T, Mitani S, Gengyo-Ando K, Baillie DL, Kohara Y and Goshima Y: Protein phosphatase 2A cooperates with the autophagy-related kinase UNC-51 to regulate axon guidance in Caenorhabditis elegans. Development 137: 1657-1667, 2010.

67. Yao H, Sun C, Hu Z and Wang W: The role of Annexin A4 in cancer. Front Biosci 21: 949-957, 2016.

68. Nagappan A, Venkatarame Gowda Saralamma V, Hong GE, Lee HJ, Shin SC, Kim EH, Lee WS and Kim GS: Proteomic analysis of selective cytotoxic anticancer properties of flavonoids isolated from Citrus platymamma on A549 human lung cancer cells. Mol Med Rep 14: 3814-3822, 2016. 